\title{
LA RESPONSABILIDAD OMISIVA DE LOS FUNCIONARIOS PÚBLICOS POR LA NO EVITACIÓN DE DELITOS: UN (NO) SISTEMA INSOSTENIBLE
}

\author{
Carmen Tomás-Valiente Lanuza \\ Universitat de les Illes Balears
}

\begin{abstract}
Resumen: En el Código penal de 1995 conviven numerosos tipos penales que en ámbitos muy diversos sancionan comportamientos omisivos de funcionarios públicos, la mayoría de los cuales consiste en la no evitación de delitos cometidos por terceras personas. El trabajo analiza este conjunto normativo - tanto las relaciones que se establecen entre los propios preceptos como la de cada uno de ellos con las reglas generales de la comisión por omisión del art. 11-y destaca su falta de coherencia sistemática, propiciadora de numerosas infracciones del principio de proporcionalidad que una interpretación jurisprudencial desigual tampoco ha contribuido a paliar; finalmente se apuntan algunas sugerencias regulativas orientadas a lograr una mayor armonía valorativa en la punición de - al menos- las conductas más frecuentes.
\end{abstract}

Abstract: Spain's 1995 Criminal Code contains several dispositions that expressly deal with omissions by public officials in different areas. Most of them consist of the non-avoidance of illegal acts committed by third parties. This varied list of omission offences creates a complex network of relationships that gives rise, in turn, to many interpretative difficulties, as regards both the relationship among some of these normative provisions and their relationship with the general clause regulating commission by omission under art. 11 of the Spanish Criminal Code. The present paper points out the lack of internal consistency within this group of offences, and the several violations of the proportionality principle, which could not be solved either by judicial interpretation. The article concludes with a set of normative proposals intended to build a more coherent system in this regard. 
Palabras clave: funcionario, policía, torturas, comisión por omisión, inspector, sujetos colaboradores,

Key words: public officer, pólice officer, torture, inspectors,

\section{INTRODUCCIÓN Y PLANTEAMIENTO.}

En la compleja configuración de las relaciones ciudadano-Estado propia de la sociedad actual (y más en concreto, en lo que se refiere a nuestra doble condición de potenciales perjudicados por y autores de comportamientos lesivos o peligrosos), puede decirse que todos somos, simultáneamente, objeto de protección y vigilancia. Operamos con la expectativa de que el Estado satisfaga su deber positivo de brindar seguridad a nuestros bienes jurídicos más esenciales, ante todo a través de una función de prevención fáctica y defensa frente al delito que recae fundamentalmente en el aparato policial y de justicia ${ }^{1}$; pero en la satisfacción de ese mismo objetivo último de garantizar la indemnidad de bienes jurídicos el Estado asume también (cada vez con mayor intensidad en el contexto actual de una actividad económica y empresarial progresivamente más compleja y generadora de riesgos) tareas de vigilancia de mayor amplitud, articuladas de modos diversos: por un lado, a través de una intensa intervención administrativa previa en determinados sectores (concesión de licencias y autorizaciones) y, por otro, y especialmente, mediante el ejercicio de una función inspectora que persigue la identificación de comportamientos infractores (y a fortiori, delictivos), imprescindible para su ulterior paralización ${ }^{2}$. Todo ello conforma una inmensa actividad estatal de vigilancia y control que se proyecta tanto sobre actividades generadoras de riesgos para bienes jurídicos individuales, o colectivos con referencia individual (seguridad e higiene en el trabajo, salud pública en materia de seguridad alimentaria o relativa a medicamentos, tráfico rodado, etc.), como sobre aquellas que pueden afectar a bienes colectivos (medio ambiente, ordenación del territorio, Hacienda Pública, etc.), y para cuyo mejor desarrollo se imponen, en determinados ámbitos, obligaciones jurídico-públicas de colaboración a sujetos privados en razón de su desempeño profesional (así, de modo pa-

1 Pero también, en última instancia, en el legislador. Una genérica obligación estatal que por supuesto es susceptible de interpretaciones maximalistas (especialmente cuando se deduce de ella un verdadero derecho subjetivo del ciudadano a la seguridad o protección) con consecuencias indeseables. Al respecto, últimamente, MARTÍNEZ GARAY, "¿Seguridad jurídica o seguridad de los bienes jurídicos? Sobre el nuevo papel de los derechos fundamentales en el discurso jurídico-penal», en Vives Antón et.al, Acción significativa, comisión por omisión y Derecho penal, Tirant lo Blanch, Valencia, 2017, pp. 267 y ss., esp. pp. 273 y ss.

2 RIVERO ORTEGA, El Estado vigilante: consideraciones jurídicas sobre sobre la función inspectora de la Administración, Tecnos, Madrid, 1999, pp. 25-9. 
radigmático, en la prevención del blanqueo de capitales y la financiación del terrorismo).

En las páginas que siguen pretende ofrecerse una visión de conjunto sobre la relevancia que en nuestro ordenamiento jurídico-penal adquiere el incumplimiento de tales deberes por los funcionarios (o eventualmente sujetos privados colaboradores) encargados del desempeño de estas tareas, centrándonos fundamentalmente en los supuestos dolosos en los que existe conciencia del delito - casos, por tanto, en los que el margen de discrecionalidad para decidir sobre la intervención se encuentra, según la expresión frecuente en la doctrina alemana, «reducido a cero»—y no se realiza la actividad indicada en cada caso para neutralizarlo o para, cuando menos, poner en marcha el procedimiento dirigido a ello ${ }^{3}$. Una visión de conjunto que permite vislumbrar un panorama, como enseguida se detallará, plagado de tipos específicos —de compleja relación entre sí y con la cláusula general del art. 11-, un tanto desconcertante cuando uno se aproxima al tema por primera vez (¿puede explicarse razonablemente la selección por el legislador de estas concretas conductas y no de otras?) y lastrado por una total descoordinación en el aspecto penológico, fruto de sucesivas reformas en las que la preocupación por la armonía sistemática brilla por su ausencia. En este sentido, el trabajo no pretende ofrecer un análisis exhaustivo de cada precepto ni de cada situación planteable, sino poner de manifiesto una serie de disfunciones sistemáticas e incoherencias punitivas (pues la mayoría de estos tipos específicos, como se verá, crean más problemas de los que resuelven y resultan, a la postre, distorsionadores) y poner de relieve cómo las afronta (si es que lo hace) la jurisprudencia.

El trabajo se centra así en las conductas omisivas de funcionarios públicos, y la colaboración de sujetos privados en la función de prevención del delito solo será abordada en relación a los casos ya mencionados de deberes jurídico-públicos o cuasi institucionales (reforzados por sanciones penales) orientados a la evitación del delito de un tercero. No nos ocuparemos aquí, por tanto — salvo alguna referencia puntual-, del sistema de responsabilidad penal de las personas jurídicas, que especialmente tras la LO 1/2015 constituye per se un epítome de un cierto desplazamiento de la tarea preventiva desde el Estado a manos privadas: en un contexto de creciente complejidad de la actividad económica y de la propia organización empresarial, acumulación de poder por las entidades mercantiles y dificultades de investigación de los delitos cometidos en su seno, uno de los fundamentos del sistema radicaría en la decisión político-criminal de hacer recaer en aquellas, al menos parcialmente, el coste de la prevención

3 Sobre el margen de discrecionalidad y las condiciones de su reducción a cero en el ámbito policial, COCA VILA, «Tirar a matar en cumplimiento de un deber. Una aproximación al fundamento y límites de los deberes positivos de protección policial», RECPC 19-24 (2017), pp. 9-21, con numerosas referencias a la doctrina alemana. 
del delito en su propio ámbito ${ }^{4}$. Dentro de ese mismo contexto, resultan también de gran interés, aunque no podamos abordarlas aquí, las múltiples cuestiones suscitadas por la estrategia político-criminal de incentivación estatal de la denuncia de comportamientos delictivos (singularmente por los empleados y los ciudadanos respecto de delitos cometidos en el seno de la actividad empresarial y de la Administración, respectivamente), una estrategia nacida en el ordenamiento norteamericano y de creciente implantación en otros países con el objetivo de mejorar la persecución de delitos en tales ámbitos (en especial, en el caso de las administraciones públicas, la corrupción) ${ }^{5}$.

Como se apuntaba, el Código penal de 1995 contiene —a diferencia de lo que sucede en otros ordenamientos, como el alemán, donde esta clase de previsiones específicas resulta mucho menos frecuente- numerosos preceptos que en ámbitos muy diversos se ocupan expresamente de conductas omisivas de funcionarios públicos, la mayoría de las cuales consisten, en concreto, en la no actuación por el funcionario (obligado a ello) ante ilícitos cometidos por terceras personas. Tal es el caso de los arts. 176 (permitir que otros ejecuten delitos de torturas), 320 (silenciar la infracción de normas de ordenación territorial o urbanística), 329 (silenciar la infracción de leyes o disposiciones normativas de carácter

4 Vid. en especial NIETO MARTÍN, La responsabilidad penal de las personas jurídicas: un modelo legislativo, Iustel, Madrid, 2008, que en el contexto esbozado supra remarca que «resulta necesario recuperar el terreno de la eficacia perdida firmando un nuevo pacto social entre el Estado y el poder corporativo, y exigiendo de las empresas que a cambio de los beneficios que les suministra su responsabilidad limitada, la apertura de los mercados o los avances tecnológicos asuman una tarea pública y se autorregulen con el fin de ponerse al lado del Estado en la tarea de controlar nuevos riesgos, proteger accionistas o consumidores o evitar hechos delictivos»(p. 38), y pp. 55-66; o GÓMEZ TOMILLO, Compliance penal y política legislativa. El deber personal y empresarial de evitar la comisión de ilícitos en el seno de las personas jurídicas, Tirant lo Blanch, Valencia, 2016, p. 19. El que el modelo de responsabilidad penal de las personas jurídicas sea en esencia «un ejemplo de privatización de funciones públicas» (así expresamente NIETO MARTÍN, «La privatización de la lucha contra la corrupción», en Arroyo Zapatero/Nieto Martín, El Derecho penal económico en la era compliance, Tirant lo Blanch, Valencia, 2013, pp. 191 y ss., p. 201) constituye precisamente el extremo más criticable para algunos de sus detractores (por todos, DÍEZ RIPOLLÉS, «La responsabilidad penal de las personas jurídicas. Regulación española», InDret 1/2012, p. 4).

5 Persecución efectiva que a su vez redundará en un mayor efecto preventivo. Especialmente relevante, RAGUÉS I VALLÈS, Whistleblowing. Una aproximación desde el Derecho penal, Marcial Pons, Madrid, 2013 (sobre los distintos métodos de incentivación de la denuncia como estrategia político-criminal vid. pp. 19 y ss.; sobre sus respectivos límites de legitimidad y la opinión del autor en favor de un sistema moderadamente incentivador, pp. 74-84). Proponen decididamente la aplicación de la figura en el sector público, entre otros, GARCÍA MORENO, «Whistleblowing como forma de prevención de la corrupción en la administración pública», en Nieto Martín/Maroto Calatayud (dirs.), Public Compliance, prevención de la corrupción en administraciones públicas y partidos políticos, Eds. Universidad Castilla-La Mancha, Cuenca, 2014, pp. 43 y ss., passim, o VIADA BARDAJÍ, «Necesarias medidas de compliance en el sector público», en Frago Amada (coord.), Actualidad Compliance 2018, Thomson/Aranzadi, Cizur Menor, 2018, pp. 187 y ss., pp. 199-200. 
general que regulan industrias o actividades contaminantes), 412.3 (denegar auxilio para evitar delitos), 414 y 415 (respectivamente, consentir que otro destruya o inutilice los medios puestos para impedir el acceso a documentos de acceso restringido, y permitir acceder a documentos secretos), o en su redacción previa a la reforma por LO 1/2015, el art. $432.1 \mathrm{Cp}$ (consentir que otro sustraiga caudales o efectos públicos). A ello se añaden dos previsiones relativas a modalidades imprudentes: el art. 576 bis 2 -que sanciona al profesional específicamente sujeto por la ley a satisfacer determinadas obligaciones orientadas a la prevención de la financiación del terrorismo cuando el incumplimiento imprudente de aquéllas diera lugar a la no evitación de delitos de esta índole-, y el lacónico tipo de blanqueo imprudente del art. 301.3 Cp, cuyo destinatario natural, según opinión doctrinal mayoritaria, es precisamente el profesional vinculado por deberes de no ejecutar y comunicar operaciones sospechosas, y en el que en principio encontrarían acomodo conductas paralelas a las tipificadas en el citado art. 576 bis $2^{6}$.

Un repaso a las respectivas penas asignadas por este variopinto conjunto de preceptos permite formular, de entrada, una primera observación.

En algunos casos, como los delitos contra la integridad moral (art. 176), infidelidad en la custodia de documentos (arts. 414-5) o la malversación en su redacción anterior a la reforma de 2015 (art. 432.1), las penas asociadas a la conducta omisiva coinciden exactamente con las previstas para la realización de la conducta activa; en tales supuestos suele entenderse mayoritariamente (aunque no de modo unánime) que nos encontramos ante tipificaciones específicas de una responsabilidad en comisión por omisión en las que la relación de equivalencia entre conducta omisiva y activa viene ya expresamente establecida por el legislador (dejando ahora al margen si se trata de autoría del propio delito omisivo o de cooperación necesaria omisiva en el delito no evitado). Poco importa, en puridad, si el precepto es considerado superfluo - por partirse de que aun sin haberse tipificado expresamente la conducta sería igualmente punible $e x$ art. $11^{7}$ - o si se le concede un mayor grado de utilidad, sea

6 Estos tipos imprudentes referidos a un cumplimiento no diligente de deberes de vigilancia por parte de sujetos colaboradores pero no funcionarios contrastan con la falta de previsiones similares respecto de estos últimos — suprimido que fue en el Cp de 1995 el art. 395 ACp, que sancionaba como modalidad culposa de malversación el abandono o negligencia inexcusable del funcionario que diera lugar a la sustracción de caudales públicos por un tercero-. Al respecto, infra IV.

Postura que podía considerarse mayoritaria respecto del consentimiento en la malversación del art. 432.1 previo a la reforma de 2015, basada en el deber de custodia de los bienes por el omitente; vid. ROCA AGAPITO, El delito de malversación de caudales públicos, Bosch, Barcelona, 1999, pp. 176-84, que acoge la postura ya sentada en su día al respecto por Suárez Montes; el que la supresión de la mención expresa a la conducta omisiva del funcionario no haya sido apenas objeto de atención en los comentarios doctrinales a la reforma abonaría este entendimiento en clave de comisión por omisión 
por entenderse que la tipificación expresa soluciona dudas interpretativas que pudieran existir respecto a la extensión de la responsabilidad genérica en comisión por omisión, sea por defenderse que directamente tipifica conductas que no hubiesen sido punibles por la cláusula general ${ }^{8}$; lo cierto es que el alcance de la responsabilidad omisiva del funcionario por la no evitación de hechos ilícitos en estos casos queda delimitada por el precepto específico y sólo por él. En otros ámbitos, en cambio (como en la denegación de auxilio del art. 412.3 o en el art. 329 respecto del medioambiente) el legislador asigna a la no evitación del delito por parte del funcionario (en principio obligado a ello) una pena inferior a la que resultaría de considerarle garante en el sentido del art. 11 y sancionar su conducta como comisión por omisión (sea de su propio delito omisivo o como partícipe en el delito del tercero). Y con ello se suscita, como es lógico, un inevitable problema interpretativo relativo a la relación entre el tipo específico y el régimen de responsabilidad que podría resultar de la aplicación de reglas generales de la comisión por omisión. El núcleo de la cuestión reside en decidir si el precepto precluye (total o parcialmente) el recurso a la comisión por comisión (relación de especialidad), por constituir una expresa e insoslayable valoración del legislador que - al margen de su mayor o menor acierto- evidenciaría la no equivalencia material entre la conducta omisiva y la activa (interpretación absolutamente mayoritaria, por ejemplo, del art. $412.3 \mathrm{Cp}$, considerado un ejemplo de omisión pura de garante), o si, por el contrario, la previsión específica no impediría el recurso a las reglas generales sobre la autoría y participación en comisión por omisión determinantes de una mayor responsabilidad, respecto de las que se encontraría en una relación de subsidiariedad tácita (como, según veremos, propone un sector doctrinal respecto al art. $329 \mathrm{y}$ algunas modalidades de delito medioambiental).

Al margen de lo anterior - esto es, de las relaciones del propio precepto con el régimen general del art. 11-, un segundo problema interpretativo que en ocasiones se suscita se refiere al significado que de estas previsiones específicas quepa deducir en relación a supuestos más

meramente declarativa y no constitutiva (así, expresamente a favor de la pervivencia de la responsabilidad en comisión por omisión del funcionario en tanto garante del patrimonio público, MIR PUIG, C., «La malversación y el nuevo delito de administración desleal en la reforma de 2015 del Código Penal español, ADPCP, vol. LXVIII, 2015, pp. 185 y ss., p. 218; vid. también STS de 7 de septiembre de 2017, que en un supuesto de este tipo cometido antes de la reforma pero enjuiciado con posterioridad no plantea siquiera que la nueva regulación pueda suponer modificación alguna de la calificación). Atribuía en cambio otra finalidad a la inclusión de la variante «consentir» (solucionar expresamente de modo sencillo problemas de calificación de la conducta del funcionario, para evitar el recurso a figuras problemáticas como la autoría mediata con instrumento doloso no cualificado o los delitos de infracción de deber), MORALES GARCIA, Los delitos de malversación, Aranzadi, Cizur Menor, 1999, pp. 281-2.

8 Todas estas posturas han sido como veremos defendidas, por ejemplo, en relación al art. $176 \mathrm{Cp}$. 
o menos «cercanos» o paralelos respecto de los que el legislador nada ha establecido expresamente. Tal cosa se plantea, por ejemplo, en el ámbito de la infidelidad de documentos (pues la previsión específica de la conducta omisiva como equivalente a la activa en los arts. 414 y 415 no se contempla respecto de la modalidad más frecuente y grave del art. 413), así como, de manera todavía más clara, respecto de la no evitación por el funcionario obligado a ello de delitos distintos de la tortura (si el art. 176 impone las mismas penas que a los autores de tales delitos «a la autoridad o funcionario que, faltando a los deberes de su cargo, permitiera que otras personas» los ejecuten, ¿qué ocurre si lo no impedido por ese mismo funcionario en idénticas circunstancias es, por ejemplo, una agresión sexual?) $)^{9}$. La solución a este tipo de dificultades parecería, con todo, relativamente sencilla: al margen de que resulte criticable la mención expresa de la conducta omisiva respecto de determinados supuestos y su no inclusión en otros tipos muy cercanos, ello puede interpretarse, en ocasiones, como un mero descuido del legislador - caso de la infidelidad en la custodia de documentos ${ }^{10}$ - o, quizás, como un afán de aclarar este extremo respecto de supuestos especialmente frecuentes - caso de la pasividad frente a las torturas-, pero no como una decisión consciente del legislador de excluir esta posibilidad respecto de los supuestos en los que la conducta pasiva no se prevea expresamente ${ }^{11}$.

Avanzaremos nuestro análisis, pues, de la mano de los tipos específicos previstos en el Cp de 1995. En primer lugar (infra II) nos ocuparemos de la responsabilidad del funcionario policial, para cuyo examen nos serviremos como hilo conductor de la nutrida jurisprudencia recaída sobre la constelación de situaciones sin duda más representativa de este contexto (los malos tratos a un detenido presenciados y no evitados por otro agente). Posteriormente (infra III) nos referiremos a las conductas omisivas de inspectores que silencian infracciones en los contextos de delitos contra el orden urbanístico y el medioambiente (arts. 320 y 329,

9 O pensemos, en sentido similar, en los Inspectores de Trabajo, Hacienda o Sanidad que silenciaran infracciones detectadas con ocasión de su labor inspectora. ¿Arrojan las previsiones expresas de los arts. 320 y 329 y las penas en ellos asignadas algún criterio respecto de la valoración jurídico-penal más adecuada de estas conductas?

10 Respecto del problema en estos concretos delitos, que no volverá a ser objeto de atención en estas páginas, puede consultarse TOMÁS-VALIENTE LANUZA, "Comentario a los arts. 413-418 (infidelidad en la custodia de documentos y de la violación de secretos)» en Gómez Tomillo (dir.), Comentarios prácticos al Código Penal, tomo V, Thomson-ReutersAranzadi, Cizur Menor, 2015, pp. 249 y ss., pp. 254-5, 258.

11 Esta es, de hecho, la interpretación dominante respecto de la no evitación por funcionarios policiales de delitos distintos de la tortura, donde contamos - tal y como veremos enseguida - con un interesante cuerpo jurisprudencial que recurre al art. 11 para sancionar al funcionario omitente. Tras la importante STS de 10 de marzo de 2016, la postura del Tribunal, como enseguida se verá, es la de que el art. 176 extiende la imputación de torturas a sujetos a los que no podría responsabilizarse con las reglas generales, pero nada significa con respecto a la aplicación de estas últimas a la no evitación de otros delitos. Sobre todo ello infra, II, 2. 
respectivamente), mientras que el siguiente apartado (infra IV) se ocupará del delito previsto por el art. 576 bis 2 en materia de financiación de terrorismo para los sujetos a deberes de colaboración —el único de todos que integra un injusto imprudente-, que no cuenta con una infracción paralela expresa en el ámbito del blanqueo de capitales, si bien doctrina y jurisprudencia le dan cabida en el blanqueo por imprudencia del art. 301.3 Cp. Por último, el apartado V acogerá algunas reflexiones y propuestas regulativas a la luz de todo lo anterior.

\section{LA RESPONSABILIDAD DEL FUNCIONARIO POLICIAL POR LA NO EVITACIÓN DE DELITOS. Criterios jurisprudenciales.}

La gran mayoría de supuestos en que en la práctica se plantea la imputación a un agente policial de responsabilidad omisiva por la no evitación de delitos presenta un sustrato fáctico harto similar: pasividad de un agente ante conductas contra la integridad moral (con la entrada en juego del art. $176 \mathrm{Cp}$ ) y/o lesiones cometidas sobre un detenido (o como mínimo informalmente «retenido») por otro agente, normalmente (aunque no solo) en comisaría. En este tipo de situaciones, los argumentos para imputar al omitente se reconducen básicamente a dos: su condición de superior jerárquico del autor, por un lado, y los deberes de custodia del detenido-retenido por otro, aunque no faltan resoluciones que aluden a un tercer (y mucho más impreciso) fundamento: el deber genérico de evitar delitos que incumbe a los miembros de las Fuerzas de Seguridad.

En los casos que atañen a delitos de torturas, la entrada en juego del art. $176 \mathrm{Cp}$ - con su imposición de la misma pena que la prevista para la autoría- explica que la jurisprudencia prescinda de ahondar en cual sea la verdadera equivalencia material de la conducta omisiva (con una autoría o con una contribución a título de participación en las torturas no evitadas). Y probablemente ello produce un cierto efecto de arrastre que explicaría que también cuando se trata de la no evitación de otros delitos se siga el mismo proceder (a pesar de que al vehicularse a través de la cláusula general del art 11, y no por el art. 176, la cuestión estaría abierta y debería ser valorada): así, cuando las torturas conllevan unas lesiones y también de estas se responsabiliza al omitente (cosa que como veremos no siempre sucede), la solución es siempre la de imponer la pena del delito no evitado, sin entrar a discutir si ello se produce a título de autor o de cooperador necesario (suele indicarse lo primero, pero sin mayores disquisiciones), y sobre todo sin plantear la posibilidad de una equivalencia valorativa con la mera complicidad ${ }^{12}$.

12 Salvo alguna referencia puntual, y sin desconocer desde luego la importancia del tema, en las páginas que siguen no ahondaremos en esta cuestión, por lo que las menciones a imputación o atribución de responsabilidad a título de comisión por omisión a quien no 
Nos centraremos pues para comenzar en los supuestos más habituales de pasividad policial (delitos sobre detenidos o retenidos) y expondremos en primer lugar el recurso a los argumentos centrales arriba mencionados por parte del Tribunal Supremo, en una jurisprudencia vacilante plena de contradicciones (infra 1) a las que la STS de 10 de marzo de 2016 ha pretendido poner fin, consiguiéndolo solo en parte y por lo demás de un modo cuestionable (2); solo después plantearemos la existencia de un deber policial de intervenir para evitar delitos derivado del tercero de los criterios mencionados, que por su propia naturaleza no se limita ya al contexto antes citado y que nos enfrenta directamente al problema del efecto oclusivo que al respecto pueda desplegar el art. 412.3 $\mathrm{Cp}$ (3), un precepto que genera a su vez múltiples problemas interpretativos (4).

\section{Superioridad y deberes de custodia. Repaso jurisprudencial $^{13}$.}

Un repaso al cuerpo jurisprudencial relativo a los malos tratos sobre personas detenidas (o informalmente retenidas) permite constatar en primer lugar la tendencia de los tribunales a, siempre que entre omitente y autor media una relación de superioridad jerárquica, basar directamente en ella la posición de garantía, de modo automático y sin mayores especificaciones sobre su fuente formal a la luz del art. 11 (a lo sumo, en alguna ocasión se alude al deber «legal» de intervención del superior); la base material del deber se encontraría, en cualquier caso, en la idea del deber de vigilancia respecto del comportamiento de los subordinados, que sí se menciona a veces de modo expreso ${ }^{14}$. Probablemente la explicación de esta tendencia a acudir directamente el principio de jerarquía se encuentre en una comprensión jurisprudencial inicial del art. 176 como

\footnotetext{
interviene para evitar el delito de un tercero han de entenderse comprensivas de ambas posibilidades (a título de autor o de partícipe). En cualquier caso, sobre este último extremo parto de la concepción mayoritaria, que para identificar una omisión con el contenido de injusto de la participación exige también la posición de garante (por más que no se trate como se sabe de una postura unánime; una panorámica al respecto, que da cuenta de las múltiples capas de la discusión sobre la participación omisiva, en RUEDA MARTÍN, ¿Participación por omisión?, Un estudio sobre la cooperación por omisión en un delito de acción doloso cometido por un acción principal, Atelier, Barcelona, 2013, pp. 35-52).

13 Una referencia algo más detallada a las sentencias recaídas hasta 2014 (lo que deja fuera el giro esencial producido con la STS de 10 de marzo de 2016) puede encontrarse en TOMÁS-VALIENTE LANUZA, " ¿Y si el Sheriff Calder hubiera permitido el linchamiento de Bubber Reeves? La Jauría Humana y el funcionario policial como garante de la evitación de delitos» en Vives Antón et.al. (dirs.), Crímenes y castigos, Miradas al Derecho penal a través del arte y la cultura, Tirant lo Blanch, Valencia, 2014, pp. 859 y ss., passim.

14 SSTS de 5 de junio 1995, 18 de julio de 1997 (torturas); STS de 28 de febrero de 2011 (lesiones). En la jurisprudencia menor, por ejemplo, SAP Cádiz de 17 de julio de 1999; SAP Vizcaya de 15 de febrero de 2001.
} 
una comisión por omisión expresamente tipificada cuyo ámbito natural de aplicación se encontraba en los superiores tolerantes con la tortura, una postura extendida en la doctrina sobre la base, al menos en parte, de que así lo apuntaría el verbo típico «permitir» ${ }^{15}$.

A pesar de los vaivenes interpretativos del TS en relación al alcance del art. 176, que enseguida examinaremos, esta asunción de la posición de garantía del superior jerárquico permanece y tras la relevante STS de 10 de marzo de 2016 ha quedado incluso reforzada (hasta el punto de que hoy considera el Tribunal que respecto del superior el art. 176 es en realidad superfluo). Ahora bien: una afirmación tan rotunda del principio de jerarquía como fundamentador directo de una posición de garantía —que además parece asumirse como suficiente per se para una equivalencia material con la autoría y fundamentar así la imputación del delito no evitado- obliga a plantearse su operatividad en cualquier otro cuerpo de la Administración cuando el superior conoce y no evita delitos cometidos por sus inferiores (malversaciones, cohechos, etc.); una responsabilidad expresamente prevista para el Derecho alemán, por cierto, en el parágrafo 357 StGB, pero no en nuestro sistema. Por supuesto, optar por esta interpretación maximalista de la relación de jerarquía en el contexto policial que ahora nos ocupa no obliga a trasladarla sin más a cualquier ámbito de la función pública: pero no hacerlo así obligaría a individualizar los rasgos de la relación jerárquica policial que determinan la afirmación de un deber de garante en dicho ámbito y no en cambio respecto de otros.

La relación de superioridad jerárquica no constituye, sin embargo, el único argumento sobre el que construir una posible responsabilidad por el delito no evitado. En tales contextos de detención concurren sobre los funcionarios policiales especiales deberes de custodia de la persona privada de libertad (en los que a la expresa previsión legal del art. 5.3b LOFCS se une una situación de dependencia material del bien jurídico, al menos en supuestos de detención en un espacio cerrado como comisaría) ${ }^{16}$; unas consideraciones extensibles a los funcionarios peni-

15 En esta línea, aun con distintos matices según los autores, vid. entre otros GARCÍA DEL BLANCO, "Tortura», en Memento Penal 2019, Francis Lefebvre, Madrid, 2019, ns.ms. 8880 y ss., n.m. 8945; GRIMA LIZANDRA, «Los delitos de tortura y de otros tratos inhumanos o degradantes cometidos por funcionarios públicos», CDJ 1996 (30), pp. 137 y ss., pp. 204-4 (si bien admite que pueda jugar una superioridad aun no jerárquica, que podría concurrir también respecto del autor activo mero particular); LASCURÁIN SÁNCHEZ, «De las torturas y otros delitos contra la integridad moral», en Bajo Fernández (dir.), Compendio de Derecho penal PE, vol II, Madrid, 1998, pp. 95-6; PEÑARANDA RAMOS, «Sobre responsabilidad en comisión por omisión respecto de hechos delictivos cometidos en la empresa (y en otras organizaciones)», Derecho y Justicia penal en el s. XXI, Colex, Madrid, 2006, pp. 411 y ss., p. 423; TAMARIT SUMALLA, "Comentario al art. 176», en Quintero Olivares (dir.)/Morales Prats (coord.), Comentarios al Código penal Español. Tomo I (arts.1-233), $7^{\mathrm{a}}$ ed., Thomson Reuters/Aranzadi, Cizur Menor, 2016, pp. 1224 y ss., pp.1226-7.

16 Los miembros de las FFCCSS «velarán por la vida e integridad física de las personas a quienes detuvieren o que se encuentren bajo su custodia y respetarán el honor y la dignidad de las personas». En esta línea, MUÑOZ SÁNCHEZ, Los delitos contra la 
tenciarios y de centros de internamiento de menores ${ }^{17}$, y cuya concurrencia convierte en puridad en irrelevante la posición de superioridad jerárquica, posibilitando así (presupuestos el resto de los requisitos propios de la comisión por omisión) la imputación de responsabilidad también al omitente de igual rango que el autor directo de los hechos.

En la jurisprudencia, sin embargo, la aceptación de esta fundamentación de la garantía sobre los deberes de custodia para con el privado de libertad no ha resultado en modo alguno pacífica. Existen, por una parte, sentencias que parecen aceptarlo, pero en las que la suficiencia de la custodia per se queda oscurecida por la referencia acumulada a la condición de superior jerárquico del omitente, también concurrente ${ }^{18}$; una dualidad argumental que también puede encontrarse en pronunciamientos relativos a funcionarios de centros de menore $^{19}$ o penitenciarios ${ }^{20}$. Pero dejando al margen estos fallos de fundamentación «mixta», resulta llamativo que durante años hayan convivido — de modo desconcertante- dos corrientes totalmente contrapuestas respecto de la cuestión.

De una parte, una línea jurisprudencial ha venido aceptando la posición de garantía de estos funcionarios sin grandes problemas, tanto respecto de la no evitación de torturas como en relación con otros de-

integridad moral, Tirant lo Blanch, Valencia, 1999, pp. 75-79; RODRÍGUEZ MESA, Torturas y otros delitos contra la integridad moral cometidos por funcionarios públicos, Comares, Granada, 2000, pp. 372, 375-6; ya respecto del precedente del actual art. 176 (párrafo quinto del art. 204 bis ACp) BARQUíN SANZ, Los delitos de tortura y tratos inhumanos o degradantes, Edersa, Madrid, 1992, p. 397 y ss. Más brevemente, entre otros, REBOLLO VARGAS, «De las torturas y otros delitos contra la integridad moral», en Córdoba Roda/ García Arán (dirs.), Comentarios al Código penal. Parte Especial, Tomo I, Marcial Pons, Barcelona, 2004, pp. 229 y ss., p. 291.

17 Sobre la posición de garantía del funcionario penitenciario, asumida como evidente por la doctrina alemana, clásico SILVA SÁNCHEZ, «Aspectos de la comisión por omisión: fundamento y formas de intervención: El ejemplo del funcionario penitenciario» CPC, núm. 38, 1989, pp. 367-404, o DEL MISMO, «Muerte violenta del recluso en un centro penitenciario: ¿solo responsabilidad patrimonial de la Administración o también responsabilidad penal de los funcionarios?», ADPCP 44 (1991), pp. 561 y ss., pp. 5635. Sigue sus planteamientos, PASTRANA I ICART, La responsabilitat penal del funcionari de presons: aspectes omissius (un estudi sobre la infracció dels deures d'intervenció en l'àmbit penitenciari), Bosch, Barcelona, 1998, pp. 277 y ss., especialmente en pp. 286-7. Igualmente, entre otros muchos, PEÑARANDA RAMOS, Capítulo 6, «Tipicidad en los delitos omisivos», Memento Penal 2019, Francis Lefebvre, Madrid, 2019, n.m. 1516, que considera garantes a los funcionarios respecto de detenidos y presos, o ROBLES PLANAS, «Deberes negativos y positivos en Derecho penal», InDret 4/2013, p. 15.

18 Vid por ejemplo STS de 2 de noviembre de 2011.

19 Así, STS de 1 de octubre de 2013, que condena ex art. $176 \mathrm{Cp}$ a la coordinadora de educadores que no interviene ante los malos tratos de todo tipo cometidos por un vigilante de seguridad sobre un menor.

20 SAP Barcelona 27 junio de 2013, en la que el art. 176 fundamenta la condena de jefes de centro y de servicio por no impedir conductas contra la integridad moral cometidas por varios funcionarios sobre internos que estaban siendo trasladados tras un motín; es confirmada por STS de 10 de marzo de 2015, que no se adentra en el problema que aquí interesa. 
$\operatorname{litos}^{21}$. Tan clara se antoja la posición de garantía por custodia a esta jurisprudencia que algunos pronunciamientos imputan al agente por el delito no evitado incluso en casos en que resulta discutible o no probado cuál de los dos funcionarios presentes realizó la acción lesiva ${ }^{22}$, operando así de modo idéntico a otros contextos (significativamente la violencia de padres sobre sus hijos menores) en que la concurrencia de deber de garantía en dos sujetos permite imputar el resultado a ambos y considerar indiferente (y por ello no necesitado de prueba) quién fuera el autor material del comportamiento lesivo y quién el que adoptara la actitud de mera pasividad $^{23}$.

De otra parte, sin embargo, diversas sentencias negaban radicalmente esta posibilidad, ya fuera por entender la jerarquía como un elemento del tipo del art. $176^{24}$, ya fuera por atribuir a los deberes de custodia de los detenidos del art. 5.3.b) LOFCS un carácter genérico, insuficiente para fundamentar sobre ellos una posición de garantía ${ }^{25}$. La relevante STS de 10 de marzo de 2016, dictada por el Tribunal con vocación expresamente reseñada de aclarar sus propias vacilaciones, viene a aclarar en parte el panorama que acaba de exponerse, si bien merced a una comprensión del art. 176 (de la que ya podían encontrarse pinceladas en alguna sentencia anterior) que genera sus propias dificultades interpretativas. Veámoslo.

21 SSTS de 19 de diciembre de 1996 o de 21 de julio de 2005; particularmente explícita STS de 1 de octubre de 2002, en un caso en que dos policías interrogan a un sujeto en un domicilio privado, golpeándole uno ante la presencia pasiva del otro. En la jurisprudencia menor vid SAP de Madrid de 28 de junio de 2001 (policías que en una detención en la vía pública no evitan que un compañero maltrate al detenido) o la más restrictiva SAP de Madrid de 28 de junio de 2003. A efectos argumentativos, admite la responsabilidad en comisión por omisión de los agentes que no evitan agresiones y abusos sexuales en comisaría, basando la posición de garante expresamente en el art. 5.3 LOFCS, SAP de Tenerife de 21 de febrero de 2011.

22 Así en STS de 30 de noviembre de 2009.

23 En algunos casos, el razonamiento se ha llevado al extremo hasta llegar a condenas manifiestamente incorrectas Así, sobre la base de encontrarse ambos en posición de garante (que se asumía sin mayor explicación, pero que implícitamente parecía fundamentarse en el deber de custodia) la STS de 5 de diciembre de 2000 condenaba a dos guardias civiles en calidad de autores accesorios por la muerte de un detenido al que uno de los dos ( $\operatorname{cin}$ que conste cuál en concreto) golpeó en la cabeza durante un conato de fuga producido cuando todavía se encontraban en la calle. Todavía más falta de argumentación se antoja la STS de 16 de enero de 1998, en la que se imputan unas lesiones en régimen de coautoría (imprudente) a los dos agentes que habían disparado sobre un sospechoso, a pesar de que aquí sí se sabía específicamente cuál de los dos había producido la lesión. Sobre ambas sentencias, con más detalle, TOMÁS-VALIENTE LANUZA, "Y si el Sheriff...?», cit., pp. 874-5.

24 Expresamente, STS de 16 de abril de 2003.

25 Así, en las dos importantes SSTS de 11 de diciembre de 2008 (caso Roquetas), que en lo que aquí nos interesa absuelve de unas lesiones omisivas y cuenta con voto particular en contra de Bacigalupo Zapater, y 4 de diciembre de 2009 (caso Bikini, relativo a una detención ilegal); obiter dicta también en STS de 26 de enero de 2010. 


\section{La STS de 10 de marzo de 2016.}

En esta resolución — decisiva para la interpretación del art. $176 \mathrm{Cp}-$, el TS confirma la condena dictada en primera instancia a un agente que permanece pasivo mientras un compañero de igual rango golpea repetidamente (y por tres veces aprieta el gatillo de la pistola descargada con la que apunta a su cabeza) a un detenido indefenso y aterrorizado, un comportamiento que solo cesa con la aparición de un superior que interviene de inmediato. Según el alto tribunal el precepto consagra una omisión pura equiparada ex lege a la acción, lo que lo hace aplicable en puridad no a los superiores jerárquicos (respecto de los que resulta superfluo, pues estos siempre sería responsables ex art. 11) sino a los compañeros del mismo rango que los autores activos (e incluso a inferiores si se dieran las necesarias condiciones de exigibilidad ${ }^{26}$ ). A partir de aquí, y en esa línea de búsqueda de un espacio propio para el art. 176, insiste el tribunal en que las torturas han de imputarse a cualquier agente presente, también (y precisamente) a los que no cumplirían con las exigencias para considerarlos garantes dimanadas del art. 11; dicho de otro modo, el Tribunal interpreta el precepto como cláusula de extensión de la autoría (o de la cooperación necesaria, cuestión ahora irrelevante) por omisión, que obedece, según el Tribunal, al especial empeño del legislador en erradicar la práctica de la tortura ${ }^{27}$.

26 Aunque admite el deber de evitar también en inferiores, la especial consideración a la posible falta de exigibilidad en estos casos ya había sido expresamente analizada por el Tribunal (así, motiva la revocación de la condena en la STS de 2015, de 22 de enero, relativa a un agente de 22 años y con solo un año en la Guardia Civil que presencia unos malos tratos infligidos por un cabo, y también es aplicada en SAP Las Palmas de 31 de marzo de 2017).

27 «El art. 176 recoge conductas omisivas que no quedarían abarcadas por los dos artículos que le preceden ni siquiera en combinación con los art. 11 y 28 y siguientes Cp». La idea de un art. 176 más extensivo que el art. 11 ya podía encontrarse en la doctrina (si bien cada autor la formula desde puntos de partida diversos que finalmente conducen a alcances muy distintos, ya sea por incluir supuestos de no garantes, ya sea por, partiendo en todo caso de sujetos garantes, extender la sanción a constelaciones en que no existiría la plena equivalencia material). Vid. BARQUíN SÁNCHEZ, Los delitos de tortura..., cit., 409-410 (en referencia a unas reglas generales de la comisión por omisión aun no positivizadas); MUÑOZ SÁNCHEZ, Los delitos..., cit., p. 75, o RODRÍGUEZ MESA, Torturas..., cit., pp. 365-367; más brevemente, LUZÓN PEÑA, Lecciones de Derecho penal Parte General, $3^{\mathrm{a}}$ ed., Tirant lo Blanch, Valencia, 2016, 31/31 y 31/114 (desde su propia concepción de la comisión por omisión) o CUERDA ARNAU, «Lección X. Torturas y otros delitos contra la integridad moral», en González Cussac (coord.), Derecho penal Parte Especial, 5a ed., Tirant lo Blanch, Valencia, 2016, pp. 177 y ss., p. 193. Otro sector doctrinal, en cambio, aboga por el carácter meramente declarativo y no constitutivo del precepto; así, SERRANO GONZÁLEZ DE MURILLO, «La responsabilidad penal de los

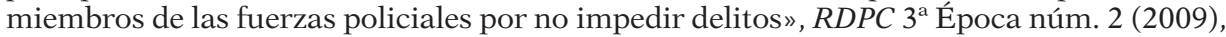
pp. 127 y ss., p. 140 nota 31 (quien insiste en la necesidad de «presumir la coherencia del legislador con sus propias premisas generales del art. $11 \mathrm{CP}$ para la omisión impropia, de las que el art. 176 supone un mero ejemplo expresamente regulado»); GRIMA LIZANDRA, «Los delitos...», cit., p. 204; MUÑZ CONDE, Derecho penal Parte Especial, 22 ${ }^{\mathrm{a}}$ ed., 
Podría pensarse que en la práctica esta concepción carece de efectos de importancia, puesto que las torturas o tratos degradantes por parte de agentes de las FFCCSS siempre se producen por definición sobre un sujeto detenido o retenido, lo que dispararía igualmente un deber de garantía dimanante de los deberes de custodia. No sería esta, a mi juicio, una deducción correcta, por varias razones: 1) aunque sin duda sea lo más habitual, no siempre estas actuaciones se producen sobre sujetos detenidos o ni siquiera «retenidos» ${ }^{28} ; 2$ ) cuando el sujeto pasivo sí reúne esta condición -incluso si los hechos se producen en comisaría- puede ser discutible si todos los agentes presentes (o simplemente conocedores de lo que sucede $)^{29}$, podrían ser considerados garantes, sobre todo si se parte de una postura restrictiva que rechaza deducir el deber penalmente relevante de las simples disposiciones jurídico-administrativas ${ }^{30} ; 3$ ) en directa conexión con lo anterior, e incluso si el omitente pudiera ser considerado garante, con las reglas generales del art. 11 quedaría todavía por examinar la equivalencia normativa, que en función de la postura más o menos restrictiva que se sustente podría terminar siendo negada.

A tenor de esta interpretación, el deber al que alude el art. 176 como ineludible elemento típico («faltando a los deberes de su cargo») no se identificaría pues con un auténtico deber de garante, sino con una obligación profesional de menor intensidad (que en el caso de los miembros de las FFCCSS vendría dada directamente por su condición de tales). Qué otros funcionarios o autoridades se encontrarían vinculados por este deber (aunque fuera genérico) convirtiéndose así en sujetos activos del art. 176 queda abierto en la jurisprudencia; más allá de los casos de funcionarios peniten-

Tirant lo Blanch, Valencia, 2019, p. 183; RODRÍGUEZ-VILLASANTE Y PRIETO, «De las torturas y otros delitos contra la integridad moral», EDJ 1996 (2), pp. 87 y ss., p. 140. Es frecuente también la alusión doctrinal a que el precepto «sirve de recordatorio» o «aclara cualquier duda» sobre la punibilidad de la conducta; así, por ejemplo, DEL ROSAL BLASCO, «Torturas y otros delitos contra la integridad moral en el Código penal de 1995», en Díez Ripollés (coord.), La ciencia del derecho penal ante el nuevo siglo. Libro homenaje al profesor doctor don José Cerezo Mir, Tecnos, Madrid, 2002, pp. 1231 y ss., p. 1239, o LASCURAÍN SÁNCHEZ, "Delitos...», cit., p. 94, que se refiere expresamente a la duda que pudiera plantearse sobre la propia comisibilidad omisiva de la afección a la integridad moral.

28 Sirva como ejemplo el caso enjuiciado por la STS de 22 de enero de 2015, referido a unos agentes de la Guardia Civil que obligan a un adolescente (sospechoso de haber intentado cometer un hurto en la playa) a meterse en el agua durante un rato mientras ellos se marchaban con sus ropas; un supuesto en el que resulta muy discutible que pueda hablarse de un detenido-retenido o custodiado y por tanto de un deber de garantía, y que con la jurisprudencia que comentamos sí es considerado incurso en el art. 176 (aunque finalmente se absolviera al omitente por consideraciones de inexigibilidad al ser los autores sus superiores jerárquicos).

${ }_{29}$ Pensemos en el que sabe que se está torturando en una parte de las dependencias policiales y simplemente se desentiende sin haber siquiera visto al detenido.

30 Así, la SAP de Madrid de 28 de junio de 2003 (que en un caso de torturas en Comisaría exigía para sancionar por el art. 176 que fueran los policías acusados los concretos encargados de la custodia de los detenidos y por tanto los garantes de sus derechos). 
ciarios directamente relacionados con la custodia del interno, que no ofrecerían ninguna duda, quizás esta concepción extensiva permitiría abarcar sujetos cuya idoneidad había sido objeto de discusión doctrinal (no, en lo que se nos alcanza, jurisprudencial), como los médicos forenses ${ }^{31}$.

Al margen de que contradecir o excepcionar las reglas generales de imputación en pos de una extensión de la responsabilidad -algo a lo que acostumbra ya nuestro legislador, especialmente en el ámbito del iter criminis- siempre resulta problemático, la consecuencia obvia de esta interpretación es la introducción de una diferencia inicial de trato que se hace depender de la naturaleza del delito no evitado: mientras que en relación a la imputación de las torturas el art. 176 exime de ahondar en ulteriores elementos determinantes de un deber de evitación (e incluso, se sobreentiende, de las ulteriores exigencias para la equivalencia normativa, que ya viene expresamente determinada por el precepto), la imputación omisiva de cualquier otro delito sí requiere una verdadera posición de garante y los restantes requisitos de la cláusula genérica -lo que en el caso concreto que dio lugar a la sentencia de 10 de marzo de 2016 determinó, de hecho, y esto resulta muy interesante, la revocación de la condena por una falta de lesiones, de modo poco comprensible- ${ }^{32}$. Una diferencia en los criterios de imputación omisiva entre las torturas y otros delitos (llamativa sobre todo cuando concurren en unos mismos hechos) que puede apreciarse también en alguna resolución posterior, a pesar de que en principio la posición de garantía por el deber de custodia del detenido no ofrecía demasiadas dudas ${ }^{33}$. Habrá quizás de esperarse

31 Los incluía ya BARQUÍN SANZ, Los delitos de tortura..., cit., p. 398, así como después en Delitos contra la integridad..., cit., p. 222; cfr. en cambio RODRÍGUEZ MESA, Torturas..., cit., p. 373, o MUÑOZ SÁNCHEZ, Los delitos..., cit., p. 78. Se refiere a las autoridades y funcionarios «de carácter judicial, policial y militar», LASCURÁIN SÁNCHEZ, «Delitos...», cit., p. 95.

32 «La diferencia apuntada entre la conducta del art. 176 y la genérica comisión por omisión sí nos llevará, no obstante, a reconsiderar la condena por la falta de lesiones: el hecho probado no define con la suficiente nitidez las exigencias que permiten equiparar respecto de las lesiones ocasionadas la conducta omisiva con la activa. En este marco delictual (art. $11 \mathrm{Cp}$ ) sí es necesario algo más que no viene afirmado con claridad en el hecho probado». Dado que los hechos se producen en comisaría, sobre un detenido aterrorizado y absolutamente indefenso (un agente le golpea repetidamente y finge dispararle en la cabeza apretando tres veces el gatillo), y habiendo sido el omitente quien se hizo cargo del detenido recepcionándole en comisaría, no consigue entenderse (y la sentencia no se detiene en aclararlo) en qué cifra el Tribunal ese «algo más» necesario para imputar también las lesiones.

33 Así, llama la atención que en la STS de 26 de septiembre de 2016 (patadas en la cabeza y puñetazos a un detenido en comisaría, presenciadas por un superior y un compañero del autor) se condene a ambos omitentes por torturas (al compañero en aplicación expresa de la doctrina sentada por la STS de 10 de marzo de 2016), y no se incluya mención alguna a las lesiones (ni siquiera para el superior, y aunque tan solo fuera para desecharlas en aplicación del principio acusatorio, pues incomprensiblemente no fueron objeto de acusación). En realidad, no parece del todo absurdo pensar que la propia existencia del art. $176 \mathrm{Cp}$, sobre todo reforzada por la interpretación que comentamos, 
a ulteriores sentencias para que (una vez ha dejado aclarada su postura sobre el ámbito aplicativo del art. 176) termine el Tribunal de perfilar si los deberes de custodia del detenido resultan o no suficientes para fundamentar una posición de garantía a efectos de imputar otros resultados lesivos no evitados - lesiones, homicidio- a agentes de inferior o igual rango que el autor (en el caso de los superiores, la imputación no ofrece dudas ex art. 11).

Por otra parte, la propia existencia del art. 176 impone una ulterior diferencia de trato en función de la naturaleza del delito omitido. Como ya se ha comentado, el art. 176 supone (al margen ahora de la interpretación del Supremo) asignar al omitente la pena del autor a todos los funcionarios presentes que pudiendo intervenir opten por no hacerlo, con independencia de que de acuerdo con las reglas generales el significado de su pasividad se ajustara mejor al desvalor de la complicidad -la sentencia que comentamos da a entender que los superiores jerárquicos en todo caso siempre habrían de ser valorados como autores o cooperadores necesarios $^{34}$, pero tal cosa no resulta en modo alguno tan evidente respecto de los compañeros, por mucho que fueran garantes-. Incluso si (en contra de la actual doctrina del TS) se entendiera que el art. 176 solo debería ser aplicado a estos últimos, este otro efecto extensivo viene en todo caso impuesto por el precepto. Tal cosa no sucede, en cambio, respecto de los restantes delitos (lesiones, agresiones sexuales), respecto de los que queda abierta la posibilidad de complicidad omisiva.

Al margen de todo lo anterior, la sentencia que comentamos sugiere una serie de reflexiones:

Al pergeñar esta interpretación extensiva de la responsabilidad ex art. 176, que desde un punto de vista material viene a justificar en el especial significado de la tortura, no parece reparar el Tribunal en que el precepto sanciona la no evitación de las conductas encuadrables en «los artículos precedentes», lo que además de las torturas en sentido estricto del art. 174 y los supuestos próximos del art. 175 (conductas también de autoridad o funcionario que sin reunir los elementos típicos de aquella sí atentaran contra la integridad moral) parece abarcar (al menos en una lectura literal del Código) delitos que, aun protegiendo igualmente dicho bien jurídico, revisten un significado radicalmente distinto y respecto de los que no se justificaría en absoluto un régimen excepcional de punición ${ }^{35}$ : el tipo básico general de trato degradante, el acoso laboral y el

puede comportar, como pernicioso efecto reflejo, el ensombrecer la operatividad del art. 11 para otros delitos también presentes en un caso.

${ }_{34}$ La cuestión no queda clara, pues el Tribunal se limita a señalar que el superior «siempre sería copartícipe del delito del art. 174».

35 En el caso de la tortura, su particular significado para el mantenimiento del Estado de Derecho ha cristalizado como es conocido en algunas otras manifestaciones de trato jurídico especialmente riguroso; recuérdese, por ejemplo, el debate sobre la imposibilidad absoluta de aplicar a este delito las reglas del estado de necesidad justificante, o sus 
relacionado con el disfrute de la vivienda (art. 173.1, $1^{\circ}, 2^{\circ}$ y $3^{\circ}$ respectivamente), y la violencia habitual de género, doméstica o cometida sobre personas sometidas a custodia o guarda en centros públicos o privados (art. 173.2) ${ }^{36}$. Que esta disfunción traiga causa de un error frecuente en la descuidada y asistemática técnica legislativa de nuestros días (introducir nuevas figuras delictivas sin atender al hecho de que les serán aplicables reglas concebidas para otros presupuestos y que respecto de ellas carecen de sentido) no nos exime de la necesidad de reparar en las implicaciones que respecto de esta cuestión podrían derivarse de la nueva postura del TS.

Desde el punto de vista de su incidencia práctica, la disfunción señalada revestiría interés, según creo, especialmente en el ámbito del acoso laboral, respecto del que resultan fácilmente imaginables actitudes de pasividad por parte de terceros cuya calificación es objeto de una ya larga controversia doctrinal ${ }^{37}$. Dejando ahora al margen la responsabilidad del superior jerárquico (que de hecho se afirmó por el Tribunal en la sentencia de 2 de abril de 2013 en el ámbito policial y que en el de la Administración local ha dado lugar también a alguna condena), recuérdese que con la doctrina que ahora comentamos, valorar la pasividad de quien conoce el acoso a la luz del art. 176 supondría responsabilizar a los compañeros del acosador (eso sí, funcionarios) que obviamente no pueden ser considerados garantes de acuerdo a las reglas generales, una excepción que si puede resultar discutible respecto de la tortura, es evidente que carece de todo sentido en estos otros contextos - pues se requeriría para imputar menos requisitos que respecto a la no evitación de delitos mucho más graves- ${ }^{38}$.

especificidades en la jurisprudencia del TEDH, entre las que destaca, en lo que ahora interesa, la imposibilidad de su indulto (sobre ello TOMÁS-VALIENTE LANUZA, «Deberes positivos del Estado y Derecho penal en la jurisprudencia del Tribunal Europeo de Derechos Humanos,» InDret Penal 3/2016, pp. 25-6).

36 Insiste especialmente en ello en sentido muy crítico por las disfunciones sistemáticas que propicia, SERRANO GONZÁLEZ DE MURILLO, «La responsabilidad penal...», cit., pp. 139-40, y en sentido similar COCA VILA, «Tirar a matar...», cit., pp. 23-4.

37 Y que gira en torno a aspectos en los que no podemos detenernos aquí, como la calificación del delito contra la integridad moral del art. $173 \mathrm{Cp}$ como de resultado o de mera actividad (calificación que impediría acudir a la comisión por omisión, así AAP Barcelona 25 julio 2012, o HUERTA TOCILDO, «La regulación de la comisión por omisión en el art. $11 \mathrm{Cp}$. Balance y problemas no resueltos», en Maqueda Abreu et.al (coords.), Derecho Penal para un estado social y democrático de Derecho. Estudios penales en homenaje al profesor Emilio Octavio de Toledo, Universidad Complutense de Madrid, 2016, pp. 137 y ss., p. 147); a no ser que se parta de interpretar el art. 11 como exigencia de un resultado jurídico y no material, premisa esta última que conduce a admitir la imputación omisiva de los delitos de mera actividad (así, expresamente para el acoso escolar, BOLEA BARDON, «Posiciones de garante frente al acoso escolar: ¿Responden penalmente los padres y docentes que no impiden el acoso?», InDret 4/2017, p. 17).

38 Afirma contundentemente la responsabilidad omisiva por no evitación de acoso laboral en el ámbito de la Administración reconduciéndola al art. 176 (si bien es cierto 
La cuestión también se plantearía respecto del acoso escolar constitutivo del tipo genérico del $173.1 \mathrm{Cp}$ en caso de pasividad de director o profesores del centro. Es cierto que en este ámbito la cuestión reviste menor importancia: en primer lugar, porque en la práctica las acusaciones por responsabilidad omisiva respecto de esta modalidad de acoso (que por cierto se han incrementado notablemente en los últimos tiempos) se articulan por la vía genérica del art. 11 y no por el art. 176, salvo alguna contada excepción ${ }^{39}$; y en segundo lugar, porque es cierto también que (incluso en el caso de vehicularse por el 176) la relajación de las exigencias sobre el deber de garante ahora sostenidas por el TS no revestiría tanta trascendencia en la medida en que en principio en el ámbito escolar concurren tanto deberes de control (del comportamiento de sujetos irresponsables eventuales autores del delito contra la integridad moral) como sobre todo deberes de protección respecto de los bienes jurídicos del menor víctima de acoso, deberes que permiten en principio identificar una posición de garantía (con todas las cautelas necesarias sobre la ulterior verdadera equivalencia con la conducta activa $)^{40}$. Con todo, si se optara por encuadrar la responsabilidad omisiva de directores o profesores (funcionarios a efectos penales) en este último precepto, la doctrina del TS podría llegar a suponer una extensión inasumible de la responsabilidad omisiva para aquellos casos en los que de aplicarse las reglas generales hubiera resultado dudosa la afirmación de la posición de garantía o la equivalencia normativa ${ }^{41}$.

que porque parte de su aplicabilidad solo a superiores jerárquicos), LAFONT NICUESA, El delito de acoso moral en el trabajo, Tirant lo Blanch, Valencia, 2008, pp. 280-1.

39 Excepcionalmente, AAP A Coruña de 30 de septiembre de 2008. En la doctrina, acude al art. 176 para profesores de enseñanza pública y al art. 11 para los de centros privados, GARCÍA VALVERDE, «Responsabilidad penal derivada del acoso escolar», en Rivas Vallejo/García Valverde (dras.), Tratamiento integral del acoso, Thomson/Aranzadi, Cizur Menor, 2015, pp. 390 y ss., p. 417 (si bien a la postre no parece sostener ninguna diferencia material entre una u otra ubicación). En contra de acudir al art. 176, remite a las reglas generales del art. 11, BOLEA BARDON, «Posiciones de garante...», cit., p. 17.

${ }_{40}$ Las acusaciones a profesores o directivos de centros educativos por responsabilidad omisiva en acoso escolar (formuladas normalmente por los padres del menor constituidos en acusación particular) suelen ser sobreseídas, pero no por ausencia de posición de garantía -que siempre se afirma-, sino por la falta de prueba de otros elementos (especialmente el conocimiento del acoso) o por estimarse que sí se produjo alguna actuación tendente a controlarlo, por mucho que fuera inadecuada o insuficiente (recuérdese que el delito no admite la modalidad imprudente, cosa en la que no parece reparar el AAP Cáceres de 9 febrero 2016 -criticado con toda razón por BOLEA BARDON, op. cit., p. 19-, que anula el sobreseimiento sobre la base de una actuación insuficiente). Vid. entre otros AAP Álava de 27 de mayo de 2005; AAP Álava de 11 septiembre de 2009; AAP Barcelona de 25 julio 2012; AAP Lleida de 22 de marzo de 2019. Todo ello, por supuesto, al margen de la responsabilidad civil del centro por los hechos lesivos cometidos en el mismo.

41 Afirmación de la equivalencia que dependerá de la postura general que sobre ello se sustente; así, siguiendo la línea sentada por Silva Sánchez, exige BOLEA BARDON (op. cit., p. 18) que el omitente hubiera asumido un compromiso específico de actuar a modo de contención del riesgo (así, cuando los padres ya se han dirigido al colegio y el 
Así las cosas, si ya antes de la ampliación de las conductas típicas del art. 173 asistían a la doctrina mayoritaria muy buenas razones (de orden sistemático, político-criminal y teleológico) para restringir la aplicabilidad de la cláusula del art. $176 \mathrm{Cp}$ a la no evitación de hechos típicos de torturas del art. 174 o del delito próximo del art. 175 (dejando fuera de su radio de acción la no evitación por funcionario de delitos genéricos contra la integridad moral del art. 173.1 cometidos por particulares) ${ }^{42}$, tanto más ha de defenderse esta interpretación restrictiva tras la enorme ampliación del contenido del art. 173 por el legislador y la del círculo de sujetos activos del art. 176 por la nueva interpretación del TS.

\section{3. ¿Un deber general de intervenir para evitar delitos?}

Volvamos a las situaciones que nos sirven de hilo conductor (los delitos cometidos sobre el detenido o interrogado por un miembro de las FFCCSS, ante la pasividad de otro). Resulta curioso que en este contexto, en el que los deberes de custodia ofrecen un anclaje en principio más sólido, algunas sentencias (ciertamente ninguna de ellas reciente) hayan optado por basar la posición de garantía del funcionario policial en un criterio mucho más amplio, a saber, un genérico deber de intervenir para evitar delitos o proteger a los ciudadanos. Un tipo de razonamiento que puede encontrarse tanto en sentencias relativas al art. $176^{43}$ como en relación a la imputación de otros delitos ${ }^{44}$.

director y/o tutores se comprometen a actuar al respecto, cosa que después desatienden por completo).

42 En este sentido RODRÍGUEZ MESA, Torturas..., cit., pp. 380-2; BARQUÍN SÁNCHEZ, Delitos contra la integridad..., cit., pp. 209-12, con referencias también a su postura respecto del párrafo quinto del art. 204 bis ACp. Igualmente, con menos detalle, MUÑOZ SÂNCHEZ, Los delitos..., cit., pp. 78 y ss.

43 Así, la STS de 18 de marzo de 1997 («eran garantes por establecerlo así el art. 5.2a de la LO 2/1986, que impone a los miembros de las FFCCSS impedir prácticas que impliquen violencia física o moral») o, todavía de modo más genérico, en STS de 25 de abril de 2001 [«el recurrente faltó de modo absoluto a la obligación de tratar de evitar de algún modo lo que estaba ocurriendo, obligación que deriva de la misma Constitución (art. 104), que asigna a la Policía la protección de los derechos de los ciudadanos, y de LFCS que desarrolla esa obligación»]. En la jurisprudencia menor sobre el art. 176 destaca la SAP de Barcelona de 21 de junio de 2012, con una vaga alusión a que los agentes condenados «debieron tratar de impedir las conductas de los otros acusados, porque no ignoraban su ilicitud penal y el abuso manifiesto que suponían». Vid igualmente la muy confusa STS 5 de noviembre de 2002, que ancla el deber de un funcionario de prisiones de intervenir para evitar unas torturas en el absurdo argumento de que conocía que la finalidad de las penas reside en la reeducación del condenado, «y tal cambio educativo no se podrá obtener mediante el procedimiento que a su presencia era aplicado»; en idéntico sentido, también en un caso de maltrato en prisión, y aunque finalmente absuelve, SAP Granada de 20 de enero de 2006.

44 SAP de Madrid de 10 de julio de 2002, que sostiene que los acusados hubieran sido cooperadores necesarios de un delito de lesiones (cometido por un compañero al 
Con todo, ocasionalmente esta argumentación se ha utilizado también en algún supuesto en el que ya no resulta tan sencillo identificar esa otra vía alternativa que permitiría prescindir de ella y fundamentar en cualquier caso una responsabilidad omisiva. Así sucede en casos en los que lo que se imputa son delitos no relacionados con la vida y la integridad física de un detenido, como la detención ilegal en sí misma ${ }^{45}$, o un allanamiento de morada cometidos por un compañero ${ }^{46}$. Y a ello podrían añadirse incluso casos fronterizos en los que la conducta lesiva se realizara sobre una persona que no reúne la condición formal de detenido, que pudieran quedar fuera de los deberes de custodia ex art. 5.3b) LOFCS si se optara por una interpretación restrictiva que no equiparara materialmente la detención a la mera retención; en este sentido, como hemos comprobado, no son extraños a la jurisprudencia casos de delitos contra la integridad moral, lesiones o incluso homicidio que se producen en esa situación intermedia, ya sea en espacios cerrados (un aparcamiento, el propio domicilio del interrogado) o en la vía pública, y que no son evitados por un compañero presente.

Recuérdese que según la nueva doctrina del TS, tratándose de delitos contra la integridad moral que disparen el juego del art. 176 todo ello ha devenido irrelevante, porque en todo caso cualquier agente presente habrá de intervenir y de no hacerlo será imputado en pie de igualdad con el autor; pero para el resto de delitos sí resultará imprescindible asentar una posición de garantía.

Ello nos sitúa ante la cuestión del deber policial de proteger a los ciudadanos y evitar delitos, o, por mejor decir -puesto que tal deber resulta innegable a la luz de la propia regulación de la institución policial, que encuentra en él su propia razón de ser- ante la necesidad de valorar hasta qué punto puede considerarse un deber jurídico-penal de intensidad suficiente para fundamentar la imputación. Un problema que, por más que en la doctrina suela confrontarse a partir del caso tipo «agente que

interrogar a un sospechoso en un aparcamiento) si hubieran presenciado directamente los hechos, al constituirse en garantes "por su condición de agentes de la autoridad y como tales obligados a la evitación de los delitos y en su caso a su persecución, y mucho más cuando se está cometiendo en su presencia».

45 SAP de Barcelona de 20 de marzo de 2001, en la que la posición de garante del omitente obedece a que «su función como agente de la autoridad es perseguir el delito y garantizar los derechos de los ciudadanos y la paz pública». La sentencia es confirmada en casación por la STS de 5 de diciembre de 2002 (que en lo que ahora interesa se limita a afirmar sin más la posición de garante -si bien quizás ello se debiera a la percepción de que igualmente podría haberse condenado al agente por su intervención activa en la detención ilegal-). Un supuesto similar, que concluye en absolución por partirse de que la agente no hubiera podido impedir la detención, en SAP Barcelona de 31 marzo 2009.

46 SAP Baleares 2086/2003, de 30 octubre, que no fundamenta siquiera la posición de garantía más allá de que el agente «debía impedir la actuación ilícita de su compañero»; la condena fue anulada por STS de 28 de abril de 2006 por inexistencia de posición de garante alguna (al no haber relación jerárquica). 
presencia un delito (de un ciudadano sobre los bienes jurídicos de otro ciudadano) y no interviene para evitarlo» ${ }^{47}$, en muy pocas ocasiones se plantea en la jurisprudencia en un contexto tan general; su campo de aplicación fáctico suele ser el más específico que acaba de examinarse (pasividad policial ante delitos cometidos por otros agentes), dentro del cual solo adquiriría relevancia, como acaba de mostrarse, en aquellos casos en que no concurriera una posición de garantía en razón de la custodia del detenido-retenido (o, según la jurisprudencia, por superioridad jerárquica $)^{48}$.

Los pocos supuestos de no intervención policial ante delitos entre particulares planteados en la jurisprudencia (bajo la imputación por el delito de omisión de auxilio del art. 412.3) suelen referirse a casos en que en puridad el agente no ha advertido el hecho típico o interviene en un momento en que todavía no es posible prever el agravamiento posterior de los hechos ${ }^{49}$.

Pues bien, la posibilidad de imputar responsabilidad en comisión por omisión a los agentes policiales por la no evitación de delitos (que suele afirmarse más como Beihilfe que como autoría), con independencia de las características de los sujetos activos (otros agentes o particulares), constituye doctrina dominante en Alemania (donde por cierto - y esto es clave- no se prevé ningún delito de omisión pura al estilo del citado art. $412.3 \mathrm{Cp}$ ), y ha sido también aceptada por el BGH (por mucho que su aplicación en la práctica real sea muy escasa) ${ }^{50}$. Entre quienes se han ocupado del tema con mayor profundidad, el debate en torno a la asignación de una posición de garantía a los funcionarios policiales (más allá de la existencia del deber de evitar delitos consagrado en el Derecho administrativo policial, que per se no se considera base suficiente de una eventual posición de garante) entronca con aspectos de largo recorrido filosófico-jurídico, como la profundización en las relaciones individuoEstado derivadas del contrato social y, en concreto, el alcance de los

47 Así PAWLIK, «El funcionario policial como garante de impedir delitos», InDret 1/2008, p.3; COCA VILA, "Tirar a matar...», cit., p. 3, o DIAS, "División de tareas y responsabilidad por omisión del funcionario policial», Lecciones y Ensayos, núm. 95, 2015, pp. 387 y ss., p. 394.

48 Sobre algunos otros casos que podrían considerarse «intermedios», más próximos a una verdadera participación en comisión por omisión, como cuando el omitente pertenece a un cuerpo o unidad específicamente dedicado a la evitación de esa concreta clase de delitos, vid infra 4.

49 Interesantes al respecto STS de 30 marzo de 2010 o SAP Sevilla de 8 marzo de 2012 .

50 El debate en Alemania no se limita, en todo caso, a la pasividad policial ante el delito, sino que se inscribe en un contexto más general relativo a la posición de garantía de los funcionarios, ya sea (según los casos) como garantes de protección o como garantes de control. Junto al de los agentes policiales, los otros supuestos objeto de mayor interés y controversia se refieren al funcionario con competencias en la protección del medio ambiente y al funcionario de los servicios sociales. Sobre ello vid infra en el texto. 
deberes estatales que de él se derivan en cuanto a la protección de sus ciudadanos (una vez descartado un genérico deber estatal de control de éstos como fuentes de peligro, sobre lo que existe acuerdo doctrinal ${ }^{51}$ ). El sector doctrinal favorable a la posición de garantía de los agentes entiende el deber de proteger y brindar seguridad a los ciudadanos como el núcleo esencial de la actividad estatal -incluso como la justificación misma del Estado-: por el contrato social los individuos renuncian a su libertad para autoprotegerse ilimitadamente a cambio precisamente de un sistema de seguridad colectiva que ampare sus bienes jurídicos (ante todo, de los ataques delictivos de los demás), una protección a la que tienen un verdadero derecho subjetivo y sobre la que construyen expectativas esenciales para el funcionamiento de la vida en sociedad (y para cuya satisfacción se reconoce a la Policía posibilidades de intervención intensas) ${ }^{52}$. El hecho de que el ciudadano disponga de ciertas cotas legítimas de autodefensa o de que pueda agenciarse privadamente medidas de seguridad (argumento empleado por la doctrina contraria para rechazar el deber de garante de los agentes) no impide la asignación primaria del deber de protección al aparato estatal: la autoprotección del ciudadano particular sólo debe entenderse como forma suplementaria de cubrir los «huecos» a los que no llega la protección del Estado, que por otra parte cuenta de facto con medios mucho más efectivos que el ciudadano ${ }^{53}$. Este punto de vista, como se decía, ha sido compartido por el BGH en algunas sentencias ${ }^{54}$.

51 Vid. por todos, PAWLIK, «El funcionario policial...», cit., passim con ulteriores referencias, o RUDOLPHI JR 1995, p. 167.

52 La afirmación de un derecho subjetivo de los ciudadanos a la protección de sus bienes jurídicos por parte del Estado ha sido tradicionalmente cara a la doctrina alemana, y engarza con derivaciones (significativamente, los deberes positivos del Estado en materia penal) de los que me he ocupado extensamente en TOMÁS-VALIENTE LANUZA, «Deberes positivos...», cit., passim.

53 Con diferentes matices, pero en lo sustancial en este sentido, entre otros muchos, BRAMMSEN, Die Entsetehungsvoraussetzungen der Garatenpflichten, Duncker \& Humboldt, Berlin, 1986, pp. 190-196; KÜHL, Strafrecht Allgemeiner Tat, $8^{\mathrm{a}}$ edición, Vahlen Verlag, München, 2017, §18 ns.ms. 83 y ss., n.m. 84; LAUBENTHAL, «Privates Wissen und strafrechtliche Verantwortlichkeit von Polizaibeamten», en Heinrich et.al (Hrsg), Festschrift für Ulrich Weber zum 70. Geburtstag, Gieseking Verlag, Bielefeld, 2004, pp. 109 y ss, pp. 111-6; ROXIN, Strafrecht Allgemeiner Tat, tomo II, Beck, München, 2003, § 32, ns.ms. 85 y ss., ns.ms. 93-95; SCHULTZ, Amtswalterunterlassen, Duncker \& Humblot, Berlin, 1984, pp. 160-6; WEIGEND, Leipziger Kommentar, de Gruyter, Berlin, 2019, com. $\S 13$, ns.ms. 30-33. Ampliamente, PAWLIK, «El funcionario policial...», passim. Una amplia y actualizada referencia al intenso debate doctrinal en Alemania sobre este punto (que por cierto contrasta con la práctica inexistencia de sentencias al respecto) puede encontrarse en COCA VILA, «Tirar a matar...», cit., pp. 20 y ss.

54 Así, BGH 38, 388 (sobre participación en comisión por omisión en un delito relativo a la prostitución) y BGH NStZ 2000, 147 (relativa a policías de delitos económicos que por sus propios intereses patrimoniales no intervienen para poner fin a una estafa que terminó causando a un banco un perjuicio de millones de marcos). Para jurisprudencia anterior vid BRAMMSEN, Die Entstehungsvoraussetzungen..., cit, p. 191, nota 228. 
A partir de estas premisas generales, la doctrina mayoritaria perfila algunas exigencias ulteriores con el fin de delimitar la extensión del deber de garante de los concretos funcionarios policiales a través de los cuales desempeña el Estado ese cometido esencial. En este sentido, suele exigirse la competencia espacial y material, y que el sujeto se encuentre de servicio (en caso contrario, p.ej. si en su tiempo libre no interviniera para impedir unas lesiones, respondería por omisión pura del § 323c); en el controvertido caso de que el agente conociera el delito encontrándose fuera de servicio pero aquel continuara cometiéndose una vez se regresa al ejercicio de la función, el deber de garantía se hace depender de una ponderación menos definida, en la que se considera ante todo la gravedad del delito ${ }^{55}$.

La idea matriz de un derecho de los ciudadanos a la seguridad o protección por parte del sistema policial y judicial presenta por supuesto múltiples ramificaciones. En estas páginas nos ocupa su repercusión en el plano estrictamente jurídico penal como posible fuente de responsabilidad de los concretos funcionarios que dolosamente omiten intervenir ante un delito de cuya comisión cierta tienen constancia, pero también despliega sus efectos en otros contextos, como las deficiencias en la detección y/o gestión del peligro de que un sujeto pueda llegar a cometer un delito sobre un ciudadano cuando de ellas se deriva la no interposición de medidas (órdenes de alejamiento en violencia de género o doméstica, imposición de vigilancia en las visitas con un menor o prohibición de estas, retirada de la patria potestad a los padres, etc.) que hubieran podido impedirlo o cuando menos dificultarlo; en todas estas situaciones la imputación de responsabilidad omisiva (imprudente) por el resultado resulta en extremo compleja, pues a las dificultades para afirmar un verdadero deber jurídico-penal de garante se añaden las inherentes (ya en sede de tipo subjetivo) a identificar una lesión de los deberes de cuidado en ámbitos profesionales caracterizados por el juego del principio de oportunidad y la necesidad de realizar juicios de pronóstico. En la jurisprudencia alemana, situaciones de este tipo han dado lugar a alguna condena por homicidio o lesiones imprudentes a trabajadores de los servicios sociales de protección de menores ${ }^{56}$; en nuestro país, en lo que se me alcanza, este

55 En el caso concreto de la StBGH 38, 388, y a pesar de sentarse las premisas generales a las que se alude en el texto, este argumento relativo a la insuficiente gravedad del delito fundamentó la absolución del policía que conoció en su tiempo libre la existencia de un delito continuado de prostitución y no hizo nada al respecto una vez reintegrado al servicio.

56 A favor, sobre la base del derecho subjetivo del menor a la protección estatal, BRINGEWAT, "Kommunale Jugendhilfe und strafrechtliche Garantenhaftung», NJW 1998, 944-7; CRAMER, «Tod eines von Sozialarbeiterin betreuten Kindes. Anmerkung», NStZ 1997, pp. 238-9 (con carácter general al margen del caso concreto comentado), o especialmente, en un amplio comentario de las sentencias en cuestión, BEULKE/ SOWODA, «Beschützergarant Jugendamt. Zur Strafbarkeit von Mitarbeitern des Jugendamtes bei Kindestod, Kindesmisshandlung oder -missbrauch innerhalb der betreuten Familie», en Dölling (hrsg.), Festschrift für Karl Gössel zum 70. Geburstag, Müller Verlag, Heidelberg, 2002, pp. 73 y ss.; la posición de garante del trabajador 
tipo de supuestos no se reconducen a la vía penal, sino a la reclamación de responsabilidad patrimonial al Estado -recuérdese el desgraciado caso González Carreño ${ }^{57}$-, o excepcionalmente a una posible responsabilidad disciplinaria del funcionario ${ }^{58}$.

Consideraciones muy similares cabría realizar respecto de la posibilidad de imputar (sea por la vía activa o en comisión por omisión) a los responsables de la concesión de permisos penitenciarios o libertad condicional respecto de los delitos cometidos durante su vigencia por quien disfruta de dichos beneficios, supuestos que en nuestro país de nuevo suelen vehicularse a través de reclamaciones de responsabilidad patrimonial a la Administración ${ }^{59}$. Aunque en la doctrina existe algún partidario de abrir la puerta en tales casos a la responsabilidad penal por el resultado ${ }^{60}$, lo cierto es que tal cosa supone un ensanchamiento casi ilimitado de una posición de garante sobre personas plenamente responsables (aunque puedan ser criminalmente peligrosas), que como excepción al principio de autorresponsabilidad debe a mi juicio enfocarse de modo más restrictivo $^{61}$. En el caso de Alemania existe alguna condena por imprudencia en

social nacería en el momento de la asunción del seguimiento de una concreta familia y de los menores en riesgo, cuyos bienes jurídicos vida e integridad sí se encontrarían en la necesaria situación de dependencia material con el funcionario; en la misma línea, entre otros, KÜHL en Strafrecht AT, cit., $\$ 18$ n.m. 78. En sentido contrario, entre otros, HASSEMER, R. "Garantenpflicht, Fachlichkeit und Technologiedefizit», en Herzog/ Neumann (Hrsg.), Festschrift für Winfried Hassemer, Müller Verlag, Heidelberg, 2010, pp. 729 y ss., passim, (donde incide no tanto en la cuestión de la posición de garantía como en las especificidades de la tarea profesional de los servicios sociales, y en especial en el "déficit tecnológico» de la impredecibilidad del comportamiento humano), o más brevemente ZACZYK, "Sobre la posición de garante de los funcionarios», en Libertad, derecho y fundamentación de la pena, Universidad Externado de Colombia, 2010, pp. 321 y ss., p. 335 (contrario a apreciar posición de garante por entender que todavía se trata de un deber funcionarial genérico).

57 Que tras un proceloso recorrido culmina con el reconocimiento de tal responsabilidad en STS Sala $3^{\mathrm{a}}$, de 17 de julio de 2018.

58 Vid. STS Sala $3^{\text {a }}$, de 19 de febrero de 2019, sobre información previa instruida por el CGPJ contra una jueza de instrucción por la no imposición de medidas cautelares a un sujeto sobre el que existían indicios de haber intentado matar a su esposa (cosa que finalmente consiguió unas semanas después en el hospital donde continuaba ingresada).

59 Vid. sobre todo STS de 16 de diciembre de 1997, y partir de ella STS de 4 de junio de 2002 y SSAN de 8 de febrero y 11 de octubre de 2006. Al respecto GONZÁLEZ ALONSO, "Sobre la responsabilidad patrimonial del Estado-Juez por delitos cometidos por condenados en libertad condicional, en tercer grado penitenciario o en disfrute de un permiso penitenciario», Diario La Ley n ${ }^{\circ}$ 6896, 4 marzo 2008. Sobre la postura del TEDH en relación a la responsabilidad del Estado en todos estos contextos, ampliamente TOMAS-VALIENTE LANUZA, «Deberes positivos...», cit., pp. 41 y ss.

60 Así FEIJOO SÁNCHEZ, op. cit., partiendo de la consideración de jueces o funcionarios como garantes de control respecto de aquellos que hayan sido o debieran haber sido condenados o sujetos a medidas cautelares.

61 Así, expresamente en contra de la postura de Feijoo, PEÑARANDA RAMOS, en Bajo Fernández (dir.), Compendio de Derecho Penal (Parte Especial), vol. I, Centro de Estudios Ramón Areces S.A., Madrid, 2003, p. 109; también restrictivo, ROBLES PLANAS, "Los dos niveles del sistema de intervención en el delito (El ejemplo de la intervención por omisión)» InDret 2/2012, pp. 13-14. 
contextos similares de concesión de permisos, pero con la fundamental diferencia de ir referidos a sujetos con problemas de imputabilidad ${ }^{62}$.

Pues bien, a mi juicio, la postura mayoritaria de la doctrina alemana (que como hemos visto asigna posición de garantía a los funcionarios policiales respecto de la evitación de delitos) no puede compartirse de lege lata en nuestro sistema, donde la existencia del delito de denegación de auxilio del art. 412.3 Cp parece comprometer su viabilidad. Es verdad, como afirma FEIJOO SÁNCHEZ en su defensa de la postura contraria a la aquí sostenida ${ }^{63}$, que el art. 412.3 «no puede afectar a la determinación del alcance de los tipos de homicidio y lesiones» eventualmente imputables en comisión por omisión a los funcionarios policiales por la no evitación de un delito, pues ciertamente cuando pueda afirmarse la posición de garantía del funcionario respecto del sujeto pasivo, lo correcto será acudir a la participación/autoría omisiva en el delito no evitado

62 Vid. el amplio comentario de SCHAFFSTEIN ( Die strafrechtliche Verantwortlichkeit Vollzugsbediensteter für den Missbrauch von Vollzugslockerungen», en Festschrift für Karl Lackner zum 70. Geburstag, de Gruyter, Berlin/New York, 1987, pp. 795 y ss., esp. pp. 802 y ss., pp. 812-3) a una condena por lesiones imprudentes al psiquiatra responsable de la concesión de una salida a un sujeto inimputable (previo autor de varios delitos sexuales, y sobre el que pesaba una medida de seguridad de internamiento), que la aprovecha para cometer nuevas agresiones, o el de ROXIN ("Anmerkung», en StV 9/2004, p. 484) a la sentencia del BGH (de 13 de noviembre de 2003) que deja abierta la posibilidad de condenar a título de imprudencia por homicidio y lesiones a los médicos que permitieron a un enfermo mental ingresado una salida no vigilada durante la que cometió dichos delitos. En sus respectivos comentarios ambos autores se muestran a favor de imputar si la decisión del profesional rebasa el riesgo permitido; vid. igualmente, PUPPE, «Verantwortlichkeit von Klinikärtzen für von Untergebrachtem bei Ausgang begangene Straftaten», NStZ 2004, pp. 554-6, o SALIGER, «Strafrechtliche Verantwortung eines Arztes für Taten eines Straftäters während des Ausganges» JZ 2004, pp. 975 y ss., passim, que pone más el acento en las dificultades de imputar responsabilidad en ámbitos lastrados por las dificultades inherentes a los juicios de pronóstico.

63 FEIJOO SÁNCHEZ, Homicidio y lesiones imprudentes. Requisitos y límites materiales, Madrid, Edijus, 1999, p. 108; DEL MISMO, «Delitos contra la Administración pública: consideraciones generales, nuevas figuras delictivas y modificación de otras conocidas», Diario La Ley, 22430/2001, p. 10. Esta misma línea, si bien escuetamente, BACIGALUPO, Delitos impropios de omisión, Dykinson, Madrid, 2005, p. 229, que dentro de la posición de garante derivada de la posición institucional del omitente destaca a los miembros de las FFCCSS (aludiendo no al deber de impedir delitos, sino expresamente al art. 5.2.a -impedir prácticas abusivas, arbitrarias o discriminatorias que impliquen violencia física o moral- y al 5.2.e —evitar un daño grave, inmediato e irreparable- de la LOFCS), o, desde un punto de vista político-criminal, LASCURAÍN SÁNCHEZ, Los delitos de omisión: fundamento de los deberes de garantía, Civitas, Madrid, 2002, pp. 138-9, y en De la Mata/Dopico/Lascuráin/Nieto, Derecho penal económico y de la empresa, _Lección 3, "La responsabilidad individual en los delitos de empresa», p. 101—, donde entiende que el policía que no evita el delito ajeno es partícipe del mismo en comisión por omisión. Apunta en este sentido de lege ferenda (con limitación a los delitos contra los bienes jurídicos individuales esenciales, y reclamando una expresa aclaración al legislador sobre la confusa situación que de lege lata genera el art. 412.3), SERRANO GONZÁLEZ DE MURILLO, "La responsabilidad...», cit., pp. 146-7, 155. Vid. igualmente DIAS, «División de tareas...», passim. 
- del mismo modo que en el ámbito no funcionarial la existencia del art. 450 no impide considerar partícipe/autor en comisión por omisión al garante que no evita el delito cometido sobre la persona a cuya protección se encuentra específicamente obligado, o la previsión del tipo agravado del art. 195.3 Cp no impide la imputación del resultado en comisión por omisión en los casos de injerencia en que se satisfagan los demás requisitos necesarios para ello-. Ahora bien, lo que el art. 412.3 sí impide, a mi entender, es que el genérico deber jurídico-público dispuesto por el art. 11 LOFCS pueda ser interpretado como fuente per se de una verdadera posición de garantía que permita fundamentar la imputación al funcionario en comisión por omisión (o, lo que a la postre viene a ser lo mismo, existe posición de garante al haber una específica previsión legal pero el art. 412.3 precluye la consideración de su omisión como materialmente equivalente a la conducta activa). Al crear el art. 412.3, el legislador ha valorado ya (como mero delito de omisión pura o, si se prefiere expresarlo así, como una omisión pura de garante) la pasividad de los funcionarios policiales (que parecen los destinatarios fundamentales de un tipo construido precisamente sobre un deber de atender los requerimientos de los particulares) ante el delito que pudieran haber evitado, calificación que a mi juicio solo será desplazada por la comisión por omisión en caso de concurrir una vinculación o dependencia más estrecha del bien jurídico —no valorada por el tipo del art. 412.3- con respecto al funcionario ${ }^{64}$.

Al margen de este argumento formal del efecto oclusivo desplegado por el art. 412.3, existen a mi juicio razones materiales convincentes para descartar la atribución a los miembros de las FFCCSS de una verdadera posición de garantía determinante de responsabilidad plena por el delito no evitado ${ }^{65}$. La verdad indudable -que la doctrina alemana gusta resal-

64 Un desarrollo de esta idea respecto del efecto oclusivo entre causas de justificación, pero trasladable a relaciones entre tipos específicos y cláusulas generales puede encontrarse en TOMAS-VALIENTE LANUZA, El efecto oclusivo entre causas de justificación, Comares, 2009, pp. 91 y ss. Considera en cambio PEÑARANDA RAMOS que (a diferencia de lo que sucedía con el art. $371 \mathrm{ACp}$, que agravaba la pena del funcionario si de su omisión se hubiera derivado grave daño para un tercero) el art. $412.3 \mathrm{Cp}$ no incorpora como elemento típico el que los delitos a los que se refiere lleguen o no a cometerse, lo que lo configura como un delito de omisión pura e impide atribuir sin más al precepto un efecto oclusivo de la responsabilidad omisiva de los funcionarios policiales por el delito no evitado [en Bajo Fernández (dir.), Compendio PE, cit., p. 116, y en igual sentido en Memento penal 2019, Francis Lefebvre, Madrid, 2019, n.m. 1518]. La cuestión es por supuesto interpretable, pero en principio entiendo que incorporar al tipo el elemento de que el delito no evitado haya llegado a tener lugar (cuando menos en grado de tentativa) permite quizás explicar mejor la diferencia de pena prevista por el precepto para el omitente en función del delito en cuestión.

65 En esta línea, por todos -aunque cada uno desde su propia concepción de las posiciones de garantía y la relación de equivalencia-, MIR PUIG, Derecho penal Parte General, $10^{\mathrm{a}}$ ed., Reppertor, Barcelona, 2015, Lecc. 12, n.m 36 (calificando de «absurdo» sancionar al agente por el delito no evitado); LUZÓN PEÑA, Lecciones PG, cit., 31/145; 
tar con el recurso al contrato social- de la asunción por el Estado como institución de la tarea de proteger y brindar seguridad a sus ciudadanos a través del aparato policial (aunque desde luego no en exclusiva, puesto que a la postre ello depende finalmente también del legislador y los órganos de Justicia ${ }^{66}$ ) no obliga necesariamente a entender que a todo funcionario policial le compete, por el hecho de serlo, un deber jurídicopenal de la máxima intensidad de evitación de delitos que satisfaga los requerimientos de equivalencia valorativa del art. $11 \mathrm{Cp}$. Las objeciones a derivar una responsabilidad por el resultado no evitado por el agente en caso de incumplimiento de sus deberes policiales de intervención -que en principio recuérdese que concurrirían también, según la LOFCS, aun no encontrándose de servicio- dependerán como es lógico de la postura que con carácter general se sustente sobre los requisitos necesarios tanto para la asunción de la posición de garante como para la apreciación de la relación de equivalencia -sea la asunción por el omitente de un compromiso específico de servir de barrera de contención de riesgos (que la pertenencia a las Fuerzas de Seguridad no incorpora per se $)^{67}$, la necesidad de una relación de estrecha dependencia que no concurriría entre los bienes jurídicos de los ciudadanos y los funcionarios policiales (pues no puede hablarse, y cada vez menos en la sociedad actual, de una incapacidad total o parcial de los ciudadanos de brindarse autoprotección) ${ }^{68}$, o posturas aun más restrictivas-; pero en todo caso, sea cual sea la perspectiva adoptada, parece en definitiva razonable entender que la mera condición de miembro de las FFCCSS no incorpora un vínculo con los bienes jurídicos de los ciudadanos (o de la colectividad) de intensidad suficiente para satisfacer los requisitos de la imputación por omisión.

Que esta se antoje, a mi juicio, la interpretación más razonable de lege lata no significa en modo alguno, por supuesto, que con ello se solucionen todas las dificultades y tensiones valorativas generadas por el art. $412.3 \mathrm{Cp}$, que parece imposible resolver de modo plenamente satisfactorio, en mayor medida aun si se consideran las generadas por la existencia de otros delitos omisivos especiales de funcionario -singularmente el art. 408 de omisión del deber de perseguir delitos, o incluso comunes, como

SCHÜNEMANN, «Die Unterlassungsdelikte und die strafrechtliche Verantwortlichkeit für Unterlassungen», ZStW 97 (1984), pp. 287 y ss., pp. 310-1. Más recientemente, COCA VILA, «Tirar a matar...», cit., pp. 26-32.

${ }_{66}$ Sobre las derivaciones que de ello extrae el TEDH de cara a deberes estatales de criminalización, investigación, enjuiciamiento y sanción efectiva de delitos me permito remitir de nuevo a mi trabajo «Deberes estatales...», cit. passim.

67 Insiste especialmente en ello, en la línea de Silva Sánchez, COCA VILA, Tirar a matar...», cit., pp. 27-8.

68 Argumento especialmente defendido por RUDOLPHI, JR 95, pp. 168 y ss., passim. Que la tarea de la prevención de delitos y seguridad se encuentra cada vez más compartida entre Estado y agentes privados es destacado en este contexto por COCA VILA, «Tirar a matar...», cit., p. 28, con referencia al en este punto expresivo Preámbulo de la Ley 5/2014 de 4 de abril, de Seguridad privada. 
el art. 450 Cp- objeto por su parte de una aplicación jurisprudencial que no contribuye precisamente a la clarificación de los problemas. A este respecto resulta necesario apuntar varias consideraciones tanto de lege lata como de lege ferenda.

\section{Problemas interpretativos generados por el art. 412.3 Cp (y su relación con otros tipos omisivos).}

Como acaba de señalarse, la mera condición de funcionario policial no permite atribuir sin más una posición de garantía al agente que no evita un delito - esto sería lo precluido, a mi juicio, por el art. 412.3-, pero la existencia de este precepto tampoco impide el recurso a la comisión por omisión (sea en régimen de autoría o de participación) en los casos en que otros deberes concurrentes permitieran atribuir al agente una especial obligación de evitación de la lesión del bien jurídico (fundamentalmente, los deberes derivados de la custodia). A partir de aquí, por supuesto, siguen en pie muchas dificultades, entre otras cosas por la entrada en juego de otros preceptos de los que todavía no nos hemos ocupado: la no persecución de delitos del art. 408 y la omisión común del deber de impedir delitos del art. 450.

Un análisis de conjunto de esta regulación positiva (sin duda confusa), del tipo de supuestos que realmente se plantean en la práctica y del tratamiento que estos últimos reciben en la jurisprudencia permite afirmar que nuestro ordenamiento jurídico no ofrece en su estado actual una respuesta adecuada a la pasividad policial frente al delito. Varios factores confluyen en esta dirección.

El primero de ellos procede de la flagrante (y muy criticada por la doctrina) incoherencia valorativa cometida por el legislador en la asignación de la pena al delito del art. 412.3, una pena totalmente insignificante per se, con el añadido de resultar considerablemente más benigna que la atribuida por el art. 450 a la no evitación de delitos por particulares; un dislate valorativo que ha pretendido paliarse articulando la sanción del funcionario que no evita un delito a través de diversos expedientes, ya sea el del concurso ideal entre el art. 450 y el 412.3 - este siempre que haya habido requerimiento- ${ }^{69}$, o un concurso de leyes con desplazamiento del segundo a favor del 450 (lo que aboca a una interpretación

69 En esta línea, con distintos argumentos, HUERTA TOCILDO, Problemas fundamentales de los delitos de omisión, Centro de Publicaciones del Ministerio de Justicia, Madrid, 1987, pp. 250-1; MUÑOZ CONDE, Derecho Penal PE, cit., p. 896 (sin descartar, con todo, que la omisión pueda ser constitutiva de participación en el delito no evitado, que en su caso absorbería el delito del 412.3); SOLA RECHE, La omisión..., cit., pp. 180183, o recientemente, COCA VILA, «Tirar a matar...», cit., p. 32. 
abrogans del 412.3$)^{70}$. En cualquier caso, estos remedios interpretativos (a los que por cierto no recurre la jurisprudencia, que en lo que se me alcanza prácticamente nunca aplica el art. 450 a policías) no eliminan el problema de base: que de modo absurdo e inexplicable nuestro Código penal asigna una pena menor a la no prestación de auxilio dirigido a evitar un delito cuando el omitente es un funcionario o autoridad (obligado a ello y requerido por un particular) que cuando se trata de un ciudadano.

Otra parte del problema reside en la propia configuración típica del art. 412.3, que al exigir requerimiento de un particular limita en grado sumo su radio de acción: al margen de aquellos casos de ataques a bienes jurídicos personales en que los víctima o los demás presentes (también particulares a efectos típicos) no requieran la intervención del agente por no estar en condiciones de hacerlo - supuestos en los que entiendo que la aplicación del tipo no vulneraría el principio de legalidad-cualquier otra no evitación de un delito por un agente, por grave que este sea, no encuentra acomodo en el precepto si falta requerimiento ${ }^{71}$. Ello impide subsumir bajo el 412.3 toda una serie de supuestos de pasividad policial que (junto a la constelación ya estudiada de no evitación de agresiones sobre el detenido o retenido cometidas por otro agente) parecen ser los más frecuentes en la práctica: la connivencia de agentes con delitos de contrabando y de tráfico de drogas. Es aquí donde los tribunales recurren al art. $408 \mathrm{Cp}$ (autoridad o funcionario que, faltando a la obligación de su cargo dejare intencionadamente de promover la persecución de los delitos de que tenga noticia o de sus responsables), cuya aplicación a este contexto merece un análisis algo más detenido.

En principio, los círculos de tipicidad de los arts. 412.3 y 408 son diferentes: el primero se refiere a la falta de intervención ante delitos de inmediata o actual ejecución, y el segundo abarcaría omitir poner en marcha los mecanismos de persecución de un delito ya cometido ${ }^{72}$.

70 Así, RUBIO LARA, Omisión del deber de impedir determinados delitos o de promover su persecución, Edersa, Madrid, 2003, p. 292 (el 412.3 se apreciaría en cambio en los casos de delitos no incluidos en el 450).

71 Cabría cuando menos plantear la posibilidad de aplicar el precepto en los supuestos en los que la víctima no requiera la intervención del agente pero su voluntad de ser socorrido fuera indudable.

72 En este sentido, claramente, REBOLLO VARGAS, «La omisión de promover la persecución de delitos. El artículo 408 del código penal», Revista de Derecho y proceso penal, núm. 2, 1999, pp. 13 y ss., pp. 41-2, o COCA VILA, «Tirar a matar...», cit., p. 25. Este es también el entendimiento que puede desprenderse de la mayoría de los comentarios doctrinales al precepto, si bien no suele incidirse en ello; a título de ejemplo, MORALES PRATS/RODRÍGUEZ PUERTA, "Art. 408», en Quintero Olivares (dir.)/Morales Prats (coord.), Comentarios al Código penal español, $7^{\mathrm{a}}$ ed., Tomo II, Thomson Reuters/ Aranzadi, Cizur Menor, 2017; ORST BERENGUER, «Lección XXXVIII, delitos contra la Administración pública (I)», en González Cussac (coord.), Derecho penal Parte Especial, Tirant lo Blanch, 5 ${ }^{\text {a }}$ ed., Valencia. 2016, p. 648; QUINTERO OLIVARES, «Art. 450», en Quintero Olivares (dir.)/Morales Prats (coord..), Comentarios al Código penal español, $7^{\mathrm{a}}$ 
Aunque ambos se ubiquen en el $\mathrm{Cp}$ como delitos contra la Administración Pública, este carácter resulta mucho más claro en la segunda figura (próxima a una suerte de encubrimiento en comisión por omisión) ${ }^{73}$; en cambio, por su propia naturaleza, la no intervención ante el delito futuro o en ejecución se sitúa en un campo fronterizo, en el que - especialmente si, como ocurre con frecuencia, la posición del agente está próxima a una verdadera posición de garantía - tendría sentido entender que su no actuación no solo interfiere con el interés público en un correcto desarrollo de su función, sino que afecta a los bienes jurídicos en trance de ser vulnerados por el delito que se renuncia a detener ${ }^{74}$.

Pues bien, el análisis de la aplicación jurisprudencial del art. 408 permite constatar que los tribunales no se sujetan a este esquema distributivo entre el art. 412.3 y el 408 , que con frecuencia se aplica a supuestos de no evitación policial de delitos próximos a ejecutarse, que se están ejecutando, permanentes o (especialmente) continuados, lo que no

ed., Tomo II, Thomson Reuters/Aranzadi, Cizur Menor, 2017, quien diferencia el art. 450 del 408 señalando que en este último el deber incumplido «nace con la mera noticia de que se ha cometido una infracción penal cuya persecución entra en la esfera de obligaciones del funcionario omitente» (cursiva añadida), o SÁNCHEZ OSTIZ GUTIÉRREZ, «Funcionario que no promueve la persecución de delitos: un caso entre el encubrimiento y la omisión del deber de impedir delitos», ADPCP 1996, pp. 1047 y ss., esp. pp. 1078-9.

73 Sobre la posibilidad de distinguir entre ambos, extensamente, SÁNCHEZ OSTIZ GUTIÉRREZ, ibídem, pp. 1078-9; considera el autor que el art. 408 sería de aplicación cuando el hecho no ha entrado todavía en el ámbito de la Administración de Justicia, mientras que el art. $451 \mathrm{Cp}$ subsumiría el comportamiento del funcionario (más grave) de frustrar (activa u omisivamente) una persecución ya comenzada.

En Alemania, la no iniciación de la persecución penal se reconduce a la figura de la Strafvereitelung in Amt del \$258a, mayoritariamente entendiéndola como una comisión por omisión; la discusión gira entonces en torno a quiénes son exactamente los funcionarios garantes a este respecto (así, por ejemplo, la sentencia del BGH 43, 82 - NStZ 1997, pp. 597 y ss., con comentario favorable de RUDOLPHI- absolvió a unos funcionarios de prisiones que no denunciaron un delito cometido sobre un interno, al no considerar dentro de sus funciones la persecución de delitos, sino sólo la ejecución de la pena; en contra expresamente, ZACZYK, «Sobre la posición...», p. 258) y, sobre todo, si debe o no condenarse cuando el delito ha sido conocido fuera del servicio - un problema que obviamente también se plantea en nuestro ordenamiento en relación al art. 408, en donde de nuevo se acude a los criterios de ponderación sentados por la sentencia BGH 38, 388; una condena derivada de los criterios interpretativos sentados a este último respecto por el BGH fue considerada conforme con el principio de legalidad penal del art. 103 GG por la sentencia del Tribunal Constitucional alemán de 21-1-2002 (recogida en $N J W$ 2003, 1030). Sobre la modulación de la obligación del funcionario de hacer uso de sus conocimientos especiales, extensamente, VACCHELLI, «En los límites del rol. Los conocimientos especiales del funcionario público», InDret 4/2017.

${ }^{74}$ A favor de considerar bienes jurídicos protegidos por el art. 412.3 los bienes individuales en juego en el delito no evitado, RUBIO LARA, Denegación de auxilio por funcionario público, CESEJ Ediciones, Madrid, 2006, pp. 48-59; no resulta convincente, en cambio, la alusión (como bienes simultáneamente protegidos en el precepto) a la seguridad ciudadana y (todavía en menor medida) al principio de autoridad. Resulta interpretable, por otra parte, qué delitos resultan abarcados por la amplia referencia del precepto a la no evitación (con requerimiento) de «cualquier otro delito» (o mal). 
parece correcto ${ }^{75}$. Ciertamente ello permite cubrir huecos propiciados por la redacción típica del 412.3, que en todos estos casos resulta inaplicable por no concurrir requerimiento de intervención, pero lo cierto es que el verbo típico «no perseguir» no parece englobar el «no evitar»o «no detener» un delito ${ }^{76}$. Por otra parte, interesa especialmente resaltar que muchos de estos supuestos se plantean respecto de agentes que, por encontrarse adscritos y/o desempeñar sus funciones en un cuerpo o unidad policial específicamente concebido para impedir (y perseguir) un determinado grupo de delitos, se hallan en una situación si no de posición de garantía, cuando menos sí muy cercana a ella, lo que, al margen de las dificultades de encuadre en los tipos omisivos que nos ocupan, determina que desde el punto de vista material ni uno ni otro ofrezca una pena adecuada al desvalor inherente a la conducta, más próximo al de una verdadera participación omisiva. El caso del agente de aduanas especialmente interesante en la medida en que ha sido tratado por el TS de un modo que evidencia sus propias dudas respecto de la posición de garantía- constituye un buen ejemplo de lo que quiere decirse.

La STS de 17 de diciembre de 2009 confirma la condena por el delito del art. $408 \mathrm{Cp}$ a un agente de aduanas de la Guardia Civil que en un puesto fronterizo deja conscientemente pasar un vehículo cargado de tabaco de contrabando. El Tribunal confirma la condena y menciona en passant la imposibilidad de imputar al agente por contrabando «al no acreditarse previo concierto" con el autor de dicho delito; tal afirmación parece significar, a contrario, que de concurrir dicho acuerdo se hubiera hecho responsable al agente en comisión por omisión (ya fuera como autor o como partícipe), lo que en puridad viene a significar que sí se le atribuye una posición de garantía ${ }^{77}$, y así lo ha entendido alguna sentencia reciente de la jurisprudencia menor ${ }^{78}$. La poca claridad de la postura del TS a este

75 Vid STS de 27 de octubre de 2006 (en un caso en el que incluso podría haberse condenado por participación activa, al tratarse de un policía que suministra información a traficante: en relación con el tráfico de drogas, solo se contempla un 408, que además se considera absorbido por el cohecho); STS de 17 de diciembre de 2009 (comentada inmediatamente infra en el texto), o STS de 4 de febrero de 2015 (policía que no interviene para evitar que un confidente compre una pistola en un contexto de «riesgo próximo de utilización del arma contra otras personas»). Sobre no intervención en delitos continuados de tráfico de drogas o contrabando vid todavía infra en el texto.

76 Una aseveración que no queda a mi juicio invalidada por la (incorrecta) rúbrica del Capítulo II del Título XX Cp (que incluye únicamente el art. 450 bajo un «De la omisión de los deberes de impedir delitos o de promover su persecución»); una razonable explicación a la sorprendente inclusión del segundo sintagma (que traería causa de avatares prelegislativos preparatorios del Código penal de 1995) ofrece REBOLLO VARGAS, "La omisión...», cit., p. 42.

77 Con todo, si realmente fuera así, el concierto de voluntades no resultaría necesario para imputar al omitente responsabilidad omisiva por el delito no evitado.

78 Aunque lo tenía vedado por el principio acusatorio, la SAP de Málaga (Secc.7 ${ }^{\mathrm{a}}$, Melilla) de 1 de julio de 2019 entiende que el Guardia Civil de Aduanas que deja pasar mercancía de contrabando debería ser sancionado como cooperador necesario de dicho delito; en este caso, aunque el funcionario, previamente conchabado con los autores, había además emitido la documentación falsa de haber llevado a cabo una inspección 
respecto se aprecia en algunas otras condenas por el art. 408 en contextos similares ${ }^{79}$.

Conviene insistir en ello: en la práctica (al menos en la reflejada jurisprudencialmente) resulta muy infrecuente que la no evitación de delitos por parte de agentes policiales se plantee en el contexto «agente que presencia un delito cometido por un particular». Lo más habitual es, como primera constelación frecuente, la pasividad ante el delito cometido por otro agente sobre un ciudadano, que aunque suela producirse en situaciones de detención en comisaría que permiten el recurso a la comisión por omisión, en no pocas ocasiones acontece en un plano intermedio (agente que presencia la propia detención arbitraria o el allanamiento cometidos por su compañero, un maltrato durante la detención pero no en comisaría, unas lesiones en comisaría pero sin una clara relación de custodia entre agente omitente y detenido - como cuando simplemente conoce lo que está pasando pero no se encuentra presente- $)^{80}$. Del mismo modo

correcta del vehículo, resulta claro que el contenido fundamental del injusto de su comportamiento, su personal contribución al hecho, no reside en la dimensión activa de su conducta sino en la omisiva.

79 Así, la STS de 10 de marzo de 2006 aplica este delito a policías de la Unidad de Sección de Especialistas Fiscales del puerto de Gijón y a un Sargento de la Guardia Civil destinado en el Grupo de Investigación Fiscal y Antidroga de la Comandancia de Gijón, que conocían y permitían (no solo no perseguían) un delito de contrabando prolongado en el tiempo cometido por un grupo de personas con las que (aunque no se dijera expresamente en los hechos) todo indica que mantenían un acuerdo. Por las razones expresadas en el texto, no resulta correcta la condena por el art. 408 (aunque es cierto que al ser una situación prolongada en el tiempo concurrían simultáneamente no evitación y no persecución), pero obviamente tampoco concurren los elementos típicos del art. 412.3 $\mathrm{Cp}$. Un supuesto similar, en el que el beneficiado por la prolongada pasividad policial es un confidente, puede encontrarse en STS de 28 abril 2006. Más correcta STS de 2 de abril de 2009 (policía nacional que en un control de embarque en un puerto detecta un DNI falso, se lo guarda y deja marchar a su portador). Incurre a mi entender en esa confusión entre impedir y perseguir, MUÑOZ CUESTA, «Omisión del deber de perseguir delitos: consentir actividad delictiva a confidente de la policía», Repertorio de jurisprudencia Aranzadi, núm. 7, 2006, pp. 21151 y ss., passim.

80 Recuérdese que según el TS si media un delito de torturas, el art. $176 \mathrm{Cp}$ hace indiferente la posición de garantía; pero esta sí sería necesaria para imputar responsabilidad omisiva por la no evitación de otros delitos (lesiones, contra la libertad sexual...), y en algunas sentencias recientes no se aprecia a pesar de tratarse de detenidos golpeados en comisaría (supra 2). Por otra parte, resulta interesante constatar que en este tipo de supuestos lo que suele plantearse ante los tribunales es la opción entre imputar responsabilidad en comisión por omisión por el resultado lesivo no evitado o directamente absolver, y no se acusa subsidiariamente por el 412.3 ni por la conducta ulterior de no haber denunciado los hechos (art. 408; en casación se lamenta de ello la STS de 22 de enero de 2015, aunque no lo aplique por impedirlo el principio acusatorio). Carece de sentido, sin embargo, que en caso de descartarse la intervención omisiva no exista un tipo intermedio subsidiariamente aplicable, y constituye un despropósito valorativo que el tipo que en principio parece previsto para ello (el 412.3) no lo sea por una falta de requerimiento del particular que obviamente no obedece a una falta de voluntad de ser socorrido, sino al hecho de percibir al agente omitente como «parte» de la agresión de que es víctima. 
(segunda constelación frecuente de supuestos) los casos de no impedimento policial de delitos de otra índole, que suelen adoptar la estructura de continuados (tráfico de drogas, contrabando) suelen ser protagonizados, en lo que se me alcanza, por funcionarios destinados en unidades o servicios expresamente dedicados a la función de evitarlos y perseguirlos, lo que ciertamente parece acercarles a una verdadera posición de garantía. Así pues, si el art. $412.3 \mathrm{Cp}$ resulta ya inadecuado para abarcar los casos (muy poco frecuentes) del agente que simplemente presencia un delito sin intervenir para evitarlo - pues por el carácter jurídico-público de su deber de intervenir necesariamente siempre debería tener más pena que un particular ${ }^{81}$, resulta inidóneo aun en mayor medida para abarcar esos casos realmente intermedios, fronterizos con una verdadera posición de garante: tanto por lo insignificante de su pena como por su propia limitación típica a supuestos de requerimiento de intervención, el art. 412.3 Cp no juega un papel de omisión pura de gravedad realmente intermedia (llamémosla o no "omisión pura de garante») capaz de captar adecuadamente el desvalor de la pasividad policial ante el delito; un papel que, por las razones comentadas, tampoco puede desempeñar el art. $408 \mathrm{Cp}$.

En las páginas que siguen repasaremos otros tipos omisivos de funcionarios expresamente previstos en nuestro Código, para —una vez analizado tanto su propio rendimiento como la coherencia entre sí y con los tipos hasta ahora examinados- formular algunas propuestas regulativas globales, que tratarán de solventar también los problemas que hemos ido poniendo de manifiesto.

\section{LA PASIVIDAD DEL FUNCIONARIO FRENTE A LOS DELITOS CONTRA LA ORDENACIÓN DEL TERRITORIO Y EL MEDIO AMBIENTE.}

Tanto en los delitos contra la ordenación del territorio como en los relativos al medioambiente nuestro Código penal prevé expresamente una conducta omisiva de funcionario en el seno de las respectivas prevaricaciones administrativas específicas. Así, el art. 320 sanciona - junto a las conductas de informar favorablemente, votar o resolver a favor de la concesión de licencias manifiestamente ilegales- al funcionario que «con motivo de inspecciones haya silenciado la infracción de dichas normas [de ordenación territorial o urbanística vigentes] o que haya omitido la realización de inspecciones de carácter obligatorio»; y en el ámbito del medioambiente el art. 329, de idéntica manera, pune al funcionario «que con motivo de sus inspecciones hubiere silenciado la infracción de leyes

81 Contundente con toda razón, COCA VILA, «Tirar a matar...», cit., pp. 31-2. 
o disposiciones normativas de carácter general que las regulen [las industrias o actividades contaminantes], o que hubiere omitido la realización de inspecciones de carácter obligatorio... ${ }^{82}$.

La tipificación expresa de las conductas de funcionarios en materia medioambiental había venido siendo reclamada por la doctrina en razón de lo que suele considerarse una especialmente intensa vinculación del bien jurídico con la actividad de la Administración, manifestada tanto en las variadas e intensas modalidades de intervención a cargo de esta (especialmente en materia de concesión de licencias y autorizaciones) como en la imprescindible labor de control a través de la inspección, vital para la protección de aquel (y expresamente encomendada a los poderes públicos por el art. $45 \mathrm{CE}$ ); centrándonos en este último aspecto, que es el que aquí interesa, la tipificación de las conductas omisivas pudo concebirse como una forma de combatir la tradicional desidia y dejadez de la Administración (denunciada incluso por la propia jurisprudencia) en el cumplimiento de dicha tarea clave. Muy pronto puso la doctrina de manifiesto, sin embargo, las dificultades interpretativas a que el nuevo tipo daba lugar en aquellos casos en que la conducta del funcionario (su voto, informe o resolución favorable a la licencia manifiestamente ilegal) pudiera ser también calificada como participación activa (especialmente cooperación necesaria) en el tipo básico del art. 325 o en sus formas agravadas, calificación respecto de la que la pena asignada por el art. 329 suponía un sorprendente privilegio punitivo ${ }^{83}$; y lo mismo sucedía, en lo

82 Dejaremos al margen de estas consideraciones esta modalidad típica omisiva de no realizar las obligadas inspecciones, que no plantea el problema que aquí interesa en relación a una posible responsabilidad del funcionario por la no evitación de delitos medioambientales o urbanísticos, y que como apuntaba con toda razón GÓRRIZ ROYO (en reflexiones referidas al art. 320, pero trasladables al 329) no parece incorporar contenido de injusto alguno que justifique la intervención penal («Prevaricaciones urbanísticas del art. 320: problemas legislativos no resueltos y dificultades aplicativas en la práctica reciente», EPC XXXVIII extr.2018, pp. 101 y ss., pp. 156-7, 160).

83 Sobre las conductas activas previstas en el art. 329, su relación de concurso de leyes con la posible calificación del hecho como participación en el delito medioambiental, y el espacio de aplicación específico del precepto $c f r$. entre otros CANCIO MELIÁ, «La responsabilidad del funcionario por delitos contra el medio ambiente en el Código penal español», ADPCP vol. LII, 1999, pp. 137 y ss., pp. 141 y ss.; MATELLANES RODRÍGUEZ, Derecho penal del medio ambiente, Iustel, Madrid, 2008, pp. 153-9; MUÑOZ CONDE/ LÓPEZ PELEGRÍN/GARCÍA ÁLVAREZ, Manual de Derecho penal ambiental, $2^{\mathrm{a}}$ ed., Tirant lo Blanch, Valencia, 2015, pp. 280-1; SILVA SÁNCHEZ/MONTANER FERNÁNDEZ, Los delitos contra el medio ambiente, Atelier, Barcelona, 2012, pp. 227-238, 247-8. Sobre los mismos problemas en relación con el art. 320 y los delitos urbanísticos, entre otros, BOLDOVA PASAMAR, Los delitos urbanísticos, Atelier, Barcelona, 2007, pp. 215 y ss., esp. 220-2; GÓMEZ TOMILLO, Urbanismo, función pública y Derecho penal, Comares, Granada, 2000, pp. 205-10, y 230-33, o GÓRRIZ ROYO, Los delitos de prevaricación urbanística, Tirant lo Blanch, Valencia, 2004, pp. 374-82, así como en «Prevaricaciones urbanísticas...», cit., pp. 112-3 (opta la autora claramente por la especialidad a favor del art. 320, a la par que insiste en su carácter fundamentalmente ampliatorio de la responsabilidad funcionarial). 
que aquí interesa, en relación con la modalidad omisiva que centrará las siguientes reflexiones.

El carácter distorsionador de los dos tipos omisivos y el hecho de que plantean muchas más dificultades interpretativas de las que resuelven puede comprobarse mediante una sencilla comparación entre sus respectivas penas puestas en relación, a su vez, con las asignadas a los correspondientes delitos activos medioambientales o urbanísticos. Veámoslo.

Antes de la reforma operada por la LO 1/2015, la pena para el funcionario omitente asignada por el art. 329 resultaba en todo caso menor a la del autor directo de un delito medioambiental del tipo básico del (anterior) art. $325 \mathrm{Cp}$. Partiendo del carácter claramente pluriofensivo del delito, y asumiendo que la pena de inhabilitación (resultante de la remisión a la pena de la prevaricación del art. 404) responde a la lesión del correcto funcionamiento de la Administración Pública, las penas abstractas de prisión y multa que responden a la afectación al bien jurídico medioambiente (prisión de seis meses a tres años y multa de ocho a veinticuatro meses) resultaban en todo caso menores que las previstas en los tipos de los delitos contra dicho bien jurídico, tanto en el tipo básico (que antes de la reforma recibía la misma pena de multa pero prisión de 2 a 5 años), como en mucha mayor medida en el agravado (que preveía las penas superiores en grado a las anteriores). Precisamente estas disparidades punitivas constituían el punto de partida de múltiples interpretaciones doctrinales - todas ellas a la búsqueda de la «verdadera voluntad» del legislador de 1995- sobre el alcance del tipo omisivo del art. 329 y su relación con el régimen general de comisión por omisión. Aunque no pueda darse cuenta aquí de modo detallado de la discusión doctrinal al respecto, baste sintetizar ahora lo esencial.

Para un sector doctrinal, la consideración del precepto a modo de una cláusula de no equivalencia expresamente dispuesta por el legislador vedaría la posibilidad de imputar al funcionario cualquier responsabilidad en comisión por omisión por el delito medioambiental no evitado; de modo más o menos expreso, este efecto oclusivo del régimen general se basa en la valoración del art. 329 como ley especial ${ }^{84}$. Según otras

84 Así, entre otros, GIMBERNAT ORDEIG, «La omisión impropia en la dogmática penal alemana: una exposición», $A D P C P$, vol. L, 1997, pp. 1 y ss., pp. 93-95, o, de modo menos explícito, DE LA MATA BARRANCO, «La obligación de control de la Administración en relación a delitos cometidos por particulares. El ejemplo de los delitos contra el ambiente», en Asúa Batarrita (ed.), Delitos contra la Administración Pública, IVAP, Bilbao, 1997, pp. 391 y ss., pp. 404-5 (autor que considera acertada la introducción del precepto), o GONZÁLEZ CUSSAC, «Sobre la prevaricación específica en los delitos contra el medio ambiente», en Quintero Olivares/Morales Prats (coords.), Estudios de Derecho ambiental. Libro homenaje al prof. Miquel Prats Canut, Tirant lo Blanch/Universitat Rovira i Virgili, Valencia, 2008, pp. 995 y ss., p. 1012. A la misma solución se llega, obviamente, desde la concepción de estos tipos como omisiones (puras) expresamente tipificadas de gravedad intermedia (ROBLES PLANAS, «Deberes negativos...», cit., nota 15 en p. 60, o DOPICO 
interpretaciones, sin embargo, dicha interpretación significaría un inadmisible privilegio punitivo para el funcionario omitente que en modo alguno pudo constituir la pretensión del legislador, siendo así que los antecedentes históricos y el análisis de la tramitación parlamentaria del precepto parecieran evidenciar todo lo contrario.

Desde este segundo punto de vista, que puede estimarse claramente mayoritario frente al anterior, se han defendido a su vez varias vías de solución del problema: un sector doctrinal, preocupado por conceder al art. 329 un ámbito de operatividad propio que no lo vacíe completamente de contenido frente al régimen general de comisión por omisión, propone entender el inciso que nos ocupa en clave de no evitación de meras infracciones administrativas (lo que dejaría la puerta abierta a responsabilizar al funcionario en comisión por omisión cuando lo no evitado fuera un delito) ${ }^{85}$; obsérvese, sin embargo, que el castigo de esta conducta

GÓMEZ-ALLER, Memento Penal económico y de la empresa 2016-7, Francis Lefebvre, Madrid, 2017, para quien el art. 329 constituye un ejemplo de que el Cp no trata como comisión por omisión el incumplimiento de un deber de evitación de delitos por parte de quienes, a pesar de ello, «no están a cargo de un foco de peligro ni del cuidado de un bien jurídico»). La cuestión problemática residiría, no obstante, en determinar si el funcionario encargado específicamente de la inspección en materia medioambiental o urbanística puede o no considerarse a cargo del cuidado del bien jurídico (o si, en la concepción de Silva Sánchez, puede decirse que ha asumido el compromiso de actuar a modo de barrera de contención de riesgos), de manera que su omisión pudiera entenderse valorativamente equivalente a una participación omisiva en el delito que conoce y no evita, de modo similar a la posibilidad de participación por omisión admitida por el propio Dopico en relación al compliance officer encargado de la recepción y gestión de denuncias que omite la conducta que habría obstaculizado el delito [vid. "Posición de garante del compliance officer por omisión del 'deber de control': una aproximación tópica», en Arroyo Zapatero/ Nieto Martín (dirs.), El Derecho penal económico en la era compliance, Tirant lo Blanch, Valencia, 2013, pp. 165 y ss., pp. 179-182].

En una línea similar, aunque con argumentos diversos y matizando según distintas situaciones, GÓRRIZ ROYO, «Omisión y tolerancia administrativa en Derecho penal del medioambiente, a propósito del art. 329.1.2 ${ }^{\circ} \mathrm{Cp}$ », Revista de Derecho y proceso penal, núm. 14, 2005, pp. 25 y ss., en esp. pp. 53-57, así como ALASTUEY DOBÓN, «El ámbito de aplicación del art. $329 \mathrm{Cp}$. Examen de sus conductas típicas», $R D P C, 2^{\mathrm{a}}$ época, núm. 9 (2002), pp. 11 y ss., pp. 29-34 (si bien finalmente esta autora se decanta "como mucho", en supuestos de connivencia con el particular, por admitir participación en omisiva en el delito no evitado). En cualquier caso, ambas autoras niegan la posibilidad de imputar al funcionario inspector la autoría omisiva del delito medioambiental sobre la base de que sus competencias no abarcan la evitación de la infracción, sino meramente la de informar sobre su existencia a los verdaderamente competentes para detenerla. Esta línea se correspondería con aquella que antes de la reforma de 2010 (que introdujo la modalidad omisiva respecto de los delitos urbanísticos) abogaba por la impunidad de la omisión funcionarial ante el delito (también por el art. 408, al considerar que no concurría obligación de perseguirlo); así, BOLDOVA PASAMAR, Los delitos urbanísticos, cit., p. 218.

85 Así, por ejemplo, GÓMEZ RIVERO, «Algunos aspectos de la responsabilidad de los funcionarios en materia ambiental», La Ley, 1996-4, p. 1243 y ss., passim, o GÓMEZ TOMILLO, «Artículo 329», en Gómez Tomillo (dir.), Comentarios prácticos al Código penal, Tomo IV, Thomson Reuters-Aranzadi, Cizur Menor, 2015, pp. 129 y ss., p. 133 (a la no denuncia de infracciones administrativas añade el autor «los casos en que el delito 
con la pena del 329 resultaría totalmente desproporcionado, puesto que incluso existiendo una dimensión de injusto del inspector que tiene que ver con el apartamiento del correcto ejercicio de la función pública de policía, el resto de la pena asignada no se corresponde a una afectación del medio ambiente merecedora de sanción penal (la infracción de base, no denunciada, no la merece en sí misma) ${ }^{86}$; una desproporción que se confirma, por otra parte, al comparar las penas de este precepto con las previstas en los arts. 408 y 412.3. Otros autores, por su parte, sí interpretan el precepto en clave de no evitación de riesgos penalmente relevantes para el medio ambiente pero optan por su desplazamiento -en un concurso de normas resuelto mediante el principio de subsidiariedad tácita- a favor de la imputación en comisión por omisión de participación o coautoría del delito no evitado, lo que supondría otorgar al precepto, desde luego, un ámbito aplicativo muy residual ${ }^{87}$.

Las cosas se complican todavía más, sin embargo, a raíz de la reforma de 2015, que desdobla el art. 325 en dos apartados y asigna al nuevo tipo del art. 325.1 un marco abstracto de seis meses a dos años de prisión, más multa de diez a catorce meses ${ }^{88}$; al hacerse tal cosa sin tocar la pena del art. 329, el resultado es que en la actualidad recibe mayor pena de prisión el funcionario inspector que silencia la infracción (seis meses a tres años) que el propio autor del delito medioambiental del art. 325.1 (que no puede superar los dos). Así pues, resulta imposible realizar afirmaciones generales sobre la correlación de penas entre el delito no evitado y el tipo omisivo - en el sentido que venía siendo criticado por gran parte de la doctrina, que detectaba en el art. 329 un privilegio punitivo respecto de las normas generales del art. 11 que no podía corresponderse con la voluntad del legislador, razón por la que se descartaba su efecto

del art. 325 tan sólo alcanza el grado de tentativa o cuando ya haya cesado la actividad contaminante»). Admite también que la no denuncia de infracciones administrativas se encontraría dentro del radio típico del precepto, ALASTUEY DOBÓN, «El ámbito...», cit., pp. 31-2.

86 En esta línea, MATELLANES RODRÍGUEZ, Derecho penal del medioambiente, cit., p. 164.

87 ACALE SÁNCHEZ, «Tutela penal del medio ambiente y funcionarios públicos», en Quintero Olivares/Morales Prats (coords.), Estudios de Derecho ambiental. Libro homenaje al prof. Miquel Prats Canut, Tirant lo Blanch/Universitat Rovira i Virgili, Valencia, 2008, pp. 819 y ss., p. 847 (imputando al funcionario autoría omisiva); CANCIO MELIÁ, «La responsabilidad...», cit., pp. 164-167 (si bien el autor pone también claramente de manifiesto los inconvenientes de esta interpretación); SILVA SÁNCHEZ/MONTANER FERNÁNDEZ, Los delitos contra el medioambiente, cit., pp. 239-40; SILVA SÁNCHEZ, Delitos contra el medio ambiente, Tirant lo Blanch, Valencia, 1999 , p. 156 nota 206, y p. 160; partiendo de una afirmación clara de la posición de garante del funcionario inspector, MATELLANES RODRÍGUEZ, Derecho penal del medioambiente, cit., pp. 162-3.

88 Sobre dónde se sitúa tras la reforma el tipo básico de delito ecológico, en un tono muy crítico, GÓRRIZ ROYO, «Delitos contra los recursos naturales y el medio ambiente (arts. 325, 326 bis, 327 y 328 CP), en González Cussac (dir.), Comentarios a la reforma del Código penal de 2015, $2^{\mathrm{a}}$ ed., Tirant lo Blanch, Valencia, 2015, pp. 1007 y ss., pp. 10131026. 
oclusivo-; tras la reforma, y sin entrar ahora en si el legislador ha sido consciente de ello, lo cierto es que a efectos penológicos el inspector omitente queda equiparado a un autor-cooperador necesario por omisión en el delito ecológico del art. 325.1 (¡incluso se le asigna un límite máximo de pena superior en un año al previsto para el autor!), equiparación que se rompe claramente respecto de los tipos más graves de los arts. 325.2 y 327 , donde el inspector omitente sí recibe una pena claramente inferior.

Similar desconcierto se producía ya a raíz de la introducción por la LO 5/2010 de una tipificación idéntica a la del 329 en los delitos contra la ordenación del territorio (art. $320 \mathrm{Cp}^{89}$ ). De modo parecido a lo que ahora sucede con el delito ecológico del nuevo art. 325.1, el art. 320 sanciona con mayor dureza la conducta del funcionario que silencia la infracción de normas de ordenación territorial o urbanística (prisión de un año y seis meses a cuatro años, más multa —más la pena de inhabilitación que responde a la dimensión prevaricadora del comportamiento-) que la propia conducta constitutiva del tipo del art. 319.2 (obras no autorizables en suelo no urbanizable: idéntica multa pero pena de prisión de uno a tres años); las penas son las mismas cuando la comparación se realiza con el tipo más castigado de delito urbanístico del art. 319.1 (obras no autorizables en suelos que gozan de una mayor protección, destinados a viales, zonas verdes, etc.). Recapitulando: el funcionario inspector que conociera y silenciara la comisión por un tercero de un delito medioambiental del art. 325.1 o de un delito urbanístico del 319.2 es equiparado penológicamente al autor (lo que parecería apuntar a que es considerado garante y su omisión equivalente a la autoría o a la cooperación necesaria), e incluso tratado con mayor dureza; dicha equiparación se mantiene en los delitos contra la ordenación del territorio respecto del tipo más grave del 319.1, pero se rompe de manera clara en delitos medioambientales cuando lo conocido por el inspector fueran delitos de los tipos más graves (que sería el ámbito en el que podría sostenerse que el tipo omisivo especial supone un privilegio penológico para el inspector, y el único en el que tras la reforma de 2015 tiene sentido la discusión doctrinal sobre si despliega o no un efecto oclusivo sobre las reglas generales de la comisión por omisión).

89 Importa reseñar que antes de la introducción de la modalidad omisiva en el art. 320 (y con independencia ahora de la pena asignada) se había condenado por autoría del delito urbanístico en comisión por omisión (esto es, acudiendo a las reglas generales) a un funcionario municipal competente para la inspección que silencia las infracciones de las que era perfecto conocedor (SAP Baleares de 23 de mayo de 2008, caso Andratx; la cuestión no fue objeto del posterior recurso de casación ante el TS). Una dureza que contrasta con otras sentencias como la STS de 2 de junio de 2015, que condena por el art. 408 a funcionarios medioambientales, con competencias para inspección y denuncia, que conocen una situación continuada de daños a bienes de dominio público (art. 263.4) y sucesivas construcciones constitutivas de delito urbanístico del art. 319. 
No parece existir una explicación plausible a toda esta desconcertante regulación, ni una interpretación que consiga hacerla coherente y eliminar toda disfunción valorativa. Dentro de esta dificultad, sí creo asumibles un par de directrices. Primera, me parece claro que el art. 329 ha de considerarse tipo especial que precluye la posibilidad de recurrir al art. 11 para resolver esos casos en que (conscientemente) el legislador rompe con la equiparación punitiva entre autor y funcionario. Segunda, que la citada equiparación, en los tipos en que se produce, aconseja una doble restricción interpretativa (que para guardar cierta homogeneidad en el tipo debería aplicarse también a los demás casos): el delito solo debería aplicarse a la no intervención del inspector ante verdaderos delitos ecológicos o urbanísticos (si se tratara de meras infracciones administrativas la vulneración del principio de proporcionalidad resultaría palmaria), y debería igualmente restringirse a situaciones en las que la actuación correcta del inspector hubiera sido idónea para detener la ejecución delictiva en curso (obra en construcción, actividad contaminante continuada), pues solo es estos casos se daría lugar a la cooperación necesaria omisiva que parece estar en la mente del legislador; si la inspección detectara una actividad delictiva ya definitivamente cesada, la omisión de denunciar debería a mi juicio reconducirse al art. 408.

En la medida en que se refieren a autoridades o funcionarios que silenciaran infracciones «con motivo de inspecciones» (art. $320 \mathrm{Cp}$ ) o «con motivo de sus inspecciones» (art. 329), los preceptos parecen restringir el círculo de sujetos activos a los inspectores ${ }^{90}$, y no parece que lo integren, por ejemplo, los Alcaldes (que no realizan tareas de inspección en sentido estricto), ni otras autoridades con competencias para autorizar o clausurar obras, explotaciones, actividades, etc., cuya calificación quedaría abierta a las reglas generales. La existencia de los tipos especiales aplicables a los inspectores, sin embargo, sí supone una pauta orientativa respecto de estos otros sujetos, pues carecería de sentido que (probado su conocimiento del delito que les compete evitar) el legislador pretendiera otorgarles un tratamiento más benigno que a los inspectores. Su tratamiento jurispru-

90 Sobre las Administraciones competentes para la inspección, la posibilidad de delegación en manos privadas y la idoneidad para ser sujeto activo del delito vid en detalle GÓRRIZ ROYO, «Prevaricaciones urbanísticas...», cit., pp. 136-9. Considera esta autora que la situación típica requiere que el funcionario presencie una infracción a raíz de una inspección (p. 155), de donde se deduce que no admitiría, por ejemplo, un mero conocimiento adquirido por otras vías; en ese mismo sentido, con razón, GÓMEZ TOMILLO, «Art. 329», cit., p. 133, que respecto de delitos medioambientales considera atípico (por más que político-criminalmente cuestionable) que el tipo no abarque al funcionario que, habiendo recibido una denuncia, no la tramite; crf. en cambio, en sede de delitos contra la ordenación del territorio, «Art. 320», cit., p. 59 (donde admite la posibilidad de una prevaricación genérica en comisión por omisión o de un delito del art. $408 \mathrm{Cp}$ ). 
dencial ha sido, con todo, desigual: benignas condenas por el art. $408^{91}$ contrastan con contundentes condenas en comisión por omisión ${ }^{92}$.

Al margen de todo lo comentado hasta el momento, conviene detenerse, siquiera brevemente, sobre la posibilidad de deducir de la tipificación de estas específicas omisiones funcionariales guías interpretativas sobre la valoración más adecuada de omisiones análogas cometidas por inspectores de otros cuerpos respecto de los delitos sometidos a su vigilancia. Como ya se mencionaba al inicio de estas páginas, el Código no se ocupa expresamente de conductas paralelas a las ahora examinadas en otros campos en los que el Estado cuenta también con un cuerpo funcionarial de inspección específicamente destinado a detectar infracciones eventualmente delictivas, que quedan así libradas a las reglas generales sobre comisión por omisión o, en su caso, a su encaje en otros tipos delictivos. Por lo que a la jurisprudencia se refiere, cabe recordar la relevante STS de 25 de abril de 2005 (caso Ardystil), que imputa a un inspector de trabajo, en comisión por omisión y a título de imprudencia (todavía bajo el peculiar régimen del art. $565 \mathrm{ACp}$ ) los resultados de muerte y lesiones sufridos por numerosas trabajadoras como consecuencia de una actividad laboral prolongada en condiciones de absoluta insalubridad, que no fueron detectadas ni denunciadas por aquel en la visita girada a los talleres de la empresa. Problemas de imputación objetiva al margen, en lo que aquí interesa resalta la contundencia con la que el TS afirma la posición de garantía del inspector, deducida de la normativa sobre sus competencias y facultades -entre las que expresamente se menciona la a mi juicio especialmente relevante de acordar la suspensión de los trabajos en casos de peligro grave para la vida o salud de los trabajadores-, firmeza que contrasta con la falta de valoraciones similares respecto de - como ejemplo especialmente relevante- los inspectores tributarios. En este último ámbito, en lo que se me alcanza, la vertiente omisiva de la conducta del funcionario se ha reconducido al art. 408 tanto en la doc-

91 Así, STS de 22 de mayo de 2013, que condena por el art. 408 a un Alcalde que conoció y no actuó en absoluto respecto de construcciones constitutivas de delito urbanístico que se encontraban en ejecución (y que, según se dice expresamente, el Alcalde tenía atribuciones para suspender). En varias ocasiones ha dejado claro el Tribunal, por otra parte, lo inadecuado de pretender reconducir la no intervención de un Alcalde a una prevaricación del art. 404 en comisión por omisión (SSTS de 3 de mayo de 2016 y 1 de febrero de 2018), más aun si lo que no se neutraliza son meras infracciones administrativas (pues se produciría una patente desproporción en relación con la pena del art. 408).

92 STS de 8 de junio de 2006, que imputa el delito ecológico en comisión por omisión a Alcalde y Director de la Agencia de Medio Ambiente por su absoluta pasividad respecto de una cantera que operaba totalmente al margen de la legalidad en terrenos del Parque natural de Sierra Nevada; por su parte, la STS de 8 de noviembre de 2011 considera al Alcalde en posición de garante y da a entender que de haber habido una pasividad absoluta hubiera imputado delito ecológico en comisión por omisión. 
trina como en la jurisprudencia ${ }^{93}$, una subsunción a mi juicio objetable si no desde el punto de vista formal, sí desde una perspectiva valorativa.

La cuestión tiene que ver, como puede fácilmente intuirse, con el momento de consumación del delito fiscal, una cuestión nada pacífica en la doctrina que como es conocido ha dado lugar a posiciones encontradas ${ }^{94}$. Aunque no pueda entrarse aquí en el tema con la profundidad que merece, comparto el entendimiento (sin duda minoritario) del delito fiscal como una infracción de estructura no formal pero sí materialmente equiparable a la del delito permanente, en la que el paso del tiempo va incrementando la lesión al bien jurídico, que de forma completa solo se produce cuando definitivamente se pierde la posibilidad de recibir el pago de la cantidad adeudada; los efectos reconocidos por el art. 305.4 $\mathrm{Cp}$ a la regularización, equiparables al desistimiento, abonarían esta concepción ${ }^{95}$. Y si esto es así respecto del comportamiento del obligado tributario, también debería desplegar sus efectos respecto de la intervención de terceros —en nuestro caso, el inspector-: el hecho de que la persecución por su parte suponga necesariamente la absoluta neutralización de la lesión del bien jurídico aproxima el desvalor de su conducta, a mi entender, más a una verdadera participación omisiva en el delito fiscal que no a una mera falta de persecución (en fase postconsumativa) de cualquier delito ya consumado, como ocurriría, por ejemplo, con la de unas lesiones o un homicidio por parte de un funcionario obligado a activarla ${ }^{96}$. La sanción por el art. 408, con su pena única de inhabilitación

93 Así, STS de 14 de noviembre de 2003 (inspector que detecta un delito fiscal y exige una compensación económica a cambio de no perseguirlo; se condena por cohecho, falsedad en documento oficial y omisión del deber de perseguir delitos). Acoge la sanción por el art. 408 para los inspectores tributarios, SÁNCHEZ OSTIZ GUTIÉRREZ, La exención de responsabilidad penal por regularización tributaria, Aranzadi, Cizur Menor, 2002, p. 179, o MORALES PRATS/RODRÍGUEZ PUERTA, «Art. 408», cit., mencionándolos expresamente dentro de la categoría genérica de los funcionarios de los cuerpos de inspección, considerados sujetos activos del delito; en contra, merced a una interpretación muy restrictiva del círculo de sujetos activos del art. 408 que remite estos supuestos a las meras infracciones disciplinarias, REBOLLO VARGAS, «La omisión...», cit., p. 23.

94 Un repaso (al hilo del estudio de la naturaleza jurídica de la regularización) en SÁNCHEZ OSTIZ GUTIÉRREZ, op.cit., pp. 151 y ss.

${ }_{95}$ Así lo defiende (y también respecto de delitos patrimoniales), MOLINA FERNÁNDEZ, «¿Qué se protege en el delito de blanqueo de capitales?: reflexiones sobre un bien jurídico problemático, y a la vez aproximación a "participación» en el delito», en Bajo Fernández/Bacigalupo (eds.), Política criminal y blanqueo de capitales, Marcial Pons, Madrid, 2009, pp. 91 y ss., pp. 101-105.

96 No quiere con ello sostenerse que la naturaleza jurídica de la regularización sea un desistimiento, como tampoco diferir la consumación del delito fiscal —en lugar de al término del período voluntario para presentar la declaración- al momento de la liquidación definitiva por parte de la Administración. Aceptar (por ser la opción más coherente con el conjunto de repercusiones dogmáticas de la fijación del momento consumativo) que el delito se perfecciona formalmente ya en el primer momento, y que la regularización no constituye por tanto un genuino desistimiento sino un comportamiento postconsumativo, no es incompatible, creo, con lo apuntado en el texto respecto del 
de seis meses a dos años (totalmente distante de la prevista para el autor del delito fiscal, que además de multa prevé de uno a cinco años de prisión - hasta seis en los supuestos agravados del art. 305 bis-) desconoce la (a mi juicio clara) lesividad de la conducta omisiva del inspector para la Hacienda Pública, y no casa en absoluto con el trato otorgado por el legislador a las omisiones de los inspectores en materia medioambiental (en el art. 329: seis meses a tres años de prisión más multa e inhabilitación ¡de nueve a quince años!) o urbanística (art. 320: un año y seis meses hasta cuatro años de prisión, más multa e idéntica inhabilitación), con penas que sí obedecen, como se ha visto, a la lesividad de su conducta respecto de los respectivos bienes jurídicos ${ }^{97}$.

Por otra parte, en varias ocasiones ha entendido la jurisprudencia de verdaderas tramas entre Inspectores de Hacienda y obligados tributarios, en las que el funcionario no se limita a dejar de perseguir una infracción ya cometida y ocasionalmente conocida, sino que como parte de esa trama aporta un compromiso de no perseguir infracciones en ejercicios subsiguientes. Aunque en algún caso de este tipo se haya condenado por cooperación necesaria activa en el delito fiscal, sin alusión alguna a la comisión por omisión, parece claro que el núcleo del injusto cometido por el funcionario es su pasividad ante las infracciones (al margen de que ello se vehicule a través de comportamientos activos como la extensión de actas incorrectas, etc. $)^{98}$; en otras ocasiones, en cambio, y de forma inexplicable, no se formuló acusación por participación en delito fiscal a los funcionarios parte de la trama delictiva, lo que supone desconocer la importancia de su contribución a la lesión de los intereses patrimoniales de la Hacienda Pública ${ }^{99}$.

En otro orden de cosas - y aunque no se trate aquí de las responsabilidades penales funcionariales que constituyen el objeto de este trabajo, sino de deberes de colaboración de particulares- no puede dejar de mencionarse en este contexto el art. $294 \mathrm{Cp}$, que sanciona con pena de

desvalor material de la omisión del inspector: que desde un punto de vista valorativo, atento a la completa neutralización de la lesividad de la conducta que se produciría de seguirse adelante con la inspección —una neutralización que sin duda el legislador toma en consideración a la hora de conceder a la regularización el trato privilegiado del desistimiento, a pesar de no serlo-, su omisión está más próxima a una verdadera participación omisiva que a una omisión del art. 408 .

97 La desproporción resultaría aun más palmaria si se entendiera, como propone un sector doctrinal, que las prevaricaciones específicas omisivas se aplicaran respecto de la no denuncia de delitos ya totalmente terminados y/o de meras infracciones administrativas.

98 De ahí que la condena por delito fiscal impida sancionar a su vez por el art. 408, no tanto por la inexigibilidad de un comportamiento que implicaría una autodenuncia como porque la omisión ya se debe entender valorada por aquella calificación — que atendería a su equivalencia con un facilitar el delito fiscal más que un mero no perseguirlo-.

99 Así sucede en el caso enjuiciado en STS de 30 de diciembre de 2013, relativa a una extensa trama de corrupción en la Inspección Tributaria de Cataluña. La condena en instancia por el art. 408 fue anulada por el TS, por otra parte, por entenderla en concurso de leyes con la prevaricación y el cohecho por los que sí se condenó. 
prisión de ¡hasta tres años! a los administradores de sociedades operativas en mercados supervisados que «negaren o impidieren la actuación de las personas, órganos o entidades inspectoras o supervisoras». Al margen de lo muy criticable de convertir la función supervisora en un bien jurídico per se (dando lugar a una infracción puramente formal desprovista de lesividad material) y de imponer con ello deberes de colaboración penalmente reforzados a los propios sujetos investigados ${ }^{100}$, no se comprende en absoluto el por qué de este contundente refuerzo de la potestad supervisora en este concreto ámbito y no en otros, por ejemplo en aquellos en los que el propio Código parece configurar esta potestad de modo especialmente relevante a la hora de asignar responsabilidades a los funcionarios (medio ambiente u ordenación del territorio) o en otros de igual o probablemente mucha mayor relevancia práctica que el seleccionado (como inspección sanitaria, laboral o tributaria). De nuevo, una selección arbitraria de un objeto de tipificación, y una asignación de penas valorativamente incoherente en el conjunto del Código.

\section{EL INCUMPLIMIENTO DE LAS OBLIGACIONES DE COLABORACIÓN DEL SECTOR PRIVADO RESPECTO DE DELITOS BLANQUEO DE CAPITALES Y FINANCIACIÓN DE TERRORISMO.}

En dos ámbitos completamente distintos de los anteriores, la financiación del terrorismo y el blanqueo de capitales, necesidades político-criminales (preventivas y de incremento de la efectividad en su persecución) han determinado a los Estados a imponer a determinados profesionales de sectores «sensibles» - especialmente operadores del sector privado bancario y financiero, canales de comisión de estos delitosobligaciones de colaboración de carácter jurídico-público orientadas al logro de tales objetivos, que en nuestro ordenamiento se contienen hoy en la Ley 10/2010, de 28 de abril, de prevención del blanqueo de capitales $\mathrm{y}$ de la financiación del terrorismo ${ }^{101}$. En este contexto, el refuerzo penal

100 Una certera crítica del precepto por estos motivos, y en general de la deriva de imponer deberes de colaboración a los propios sujetos investigados, en SILVA SÁNCHEZ, «Hacia el Derecho penal del «Estado de la prevención». La protección penal de las agencias administrativas de control en la evolución de la Política Criminal», en Silva Sánchez (dir.) ¿Libertad económica o fraudes punibles?, Marcial Pons, Madrid-Barcelona 2003, pp. 307 y ss., esp. 320-1.

101 Sobre las funciones de esta responsabilización del sector privado en la política criminal de reducción del blanqueo, desde una perspectiva de análisis económico del Derecho, BERMEJO, Prevención y castigo del blanqueo de capitales. Un análisis jurídicoeconómico, Marcial Pons, Madrid/Barcelona/Buenos Aires/Sao Paulo, 2015, pp. 241-61. Un tono crítico con esta «extensión de la responsabilidad mediante transferencia de funciones policiales de colaboración con la Administración a particulares» en SILVA 
de estas obligaciones administrativas se vehicula no a través de tipos omisivos dolosos como los previstos para funcionarios en los ámbitos que hemos examinado, sino mediante la sanción de cumplimientos deficientes en la medida en que den lugar a la comisión de delitos dolosos por los clientes ${ }^{102}$. Ahora bien: en una nueva muestra de disparidad a la hora de tratar conductas sustancialmente iguales —como acabamos de ver que en parte también sucede respecto de las conductas omisivas de funcionarios en delitos medioambientales y urbanísticos-, el legislador no diseña del mismo modo el refuerzo penal del cumplimiento de tales deberes en una y otra sede.

En el caso del blanqueo, como es conocido, no existe en nuestro Código una conducta expresamente referida a los profesionales, si bien la doctrina mayoritaria los tiene por los destinatarios naturales del lacónico y per se problemático tipo de blanqueo imprudente del art. 301.3 $\mathrm{Cp}$ (que castiga con prisión de seis meses a dos años y multa del tanto al triplo al que por imprudencia grave realizase los hechos previamente descritos como modalidades dolosas de conducta) ${ }^{103}$. En lo que aquí nos interesa ha de precisarse (y esto también es aplicable respecto de la financiación del terrorismo) que la cuestión se plantea de modo distinto en función del tipo de obligación incumplida por el sujeto colaborador. En efecto, en la medida en que la actividad de estos profesionales constituye la puerta o el canal que el blanqueador necesita para conseguir su objetivo, la obligación primaria que inicialmente se les impone es la de actuar a modo de gatekeepers, esto es, un deber negativo de no ejecutar operaciones sospechosas; en caso de haber «abierto la puerta» por no haber advertido su carácter delictivo, la responsabilidad del sujeto colaborador emanará directamente de dicho comportamiento activo, y resultará, en principio menos problemática ${ }^{104}$. En cambio, si el incumplido es el deber estrictamente positivo de comunicar la operación sospechosa (esto es, de actuar como whistleblower, por utilizar la expresión cada vez

SÁNCHEZ, «Los delitos patrimoniales y económico-financieros», Diario La ley núm. 7534 (23-12-2010).

102 El incumplimiento de tales deberes per se solo supone infracción administrativa ex art. 51.1 Ley 10/2010.

${ }_{103}$ Así, entre otros muchos, BERMEJO, Prevención..., cit., pp. 325-7; BLANCO CORDERO, El delito de blanqueo de capitales, $4^{\mathrm{a}}$ ed ( $2^{\mathrm{a}}$ en Grandes Tratados), Thomson Reuters/Aranzadi, Cizur Menor, 2015, pp. 88-901; DÍAZ MAROTO, «Blanqueo de capitales», en Memento penal 2019, Francis Lefebvre, Madrid, 2019, ns.ms.12385 y ss., n.m.12437. Al margen de ello, como se sabe, no resulta en absoluto pacífico, ni lege lata ni de lege ferenda, si también los ciudadanos no profesionales pueden y deben ser considerados sujetos activos de este delito imprudente. Sobre esta polémica, por todos, BLANCO CORDERO, op. cit., pp. 868-902.

104 Así, respecto de los notarios con carácter general, SILVA SÁNCHEZ, «La intervención de notarios en la comisión de delitos patrimoniales y económicos», en Judicatura y notariado ante los delitos económicos, EDJ núm. 73, CGPJ, Madrid, 2006, pp. 167 y ss., pp. 183-6; en igual sentido para el ámbito del blanqueo, BERMEJO, op.cit. p. 245. 
más habitual) — supuesto en el que pueden incurrir, por ejemplo, superiores de quien ha realizado la operación, obligados a supervisarla-, la responsabilidad del sujeto colaborador sería ya puramente omisiva, y su encuadre en el art. $301.3 \mathrm{Cp}$-que le sancionase como autor por omisión de su propio delito imprudente por no haber evitado el blanqueo doloso de un tercero- presupondría admitir posición de garantía y relación de equivalencia. Dado que el tipo del 301.3 no parece prejuzgar ninguno de ambos extremos (su laconismo no permite considerarlo una cláusula de equivalencia expresamente valorada por el legislador), la cuestión está abierta a la interpretación de acuerdo a las reglas generales del art. 11 Cp: frente a quienes afirman todos los elementos de esa imputación por omisión, el TS, en cambio, no parece por el momento entenderlo así ${ }^{105}$.

Por su parte, el caso del incumplimiento de obligaciones de colaboración en el ámbito de la financiación del terrorismo sí que es objeto de una tipificación mucho más específica que la que acaba de examinarse respecto del blanqueo. Así, el art. 576.4, introducido en la reforma operada por la LO 5/2010 y hasta el momento inaplicado, sanciona a quien estando «específicamente sujeto por la Ley a colaborar con la autoridad en la prevención de las actividades de financiación del terrorismo dé lugar, por imprudencia grave en el cumplimiento de dichas obligaciones, a que no sea detectada o impedida cualquiera de las conductas [de financiación dolosa del terrorismo] descritas en el apartado 1», lo que determina la imposición de la pena inferior en uno o dos grados a la prevista para el delito correspondiente. Sin entrar ahora en si la conducta hubiera encontrado una más atinada ubicación en los delitos de blanqueo, por ser este realmente su contenido de injusto - como proponen algunos autores de acuerdo con el modelo alemán- ${ }^{106}$, interesa reparar en un par de aspec-

105 Expresamente señala la STS de 23 de septiembre de 2010 que el no cumplimiento de los deberes administrativos de comunicación no satisface los requisitos de equivalencia propios de la comisión por omisión del art. $11 \mathrm{Cp}$; en aplicación (a mi juicio algo confusa) de esta esta doctrina absuelve de blanqueo imprudente a un empleado bancario la reciente SAP Málaga (secc. $7^{\mathrm{a}}$, Melilla) de 26 de diciembre de 2018. Vid. en cambio la interesante sentencia del Tribunal Federal Suizo de 3 de noviembre de 2010 (analizada con detalle por BLANCO CORDERO, El delito..., cit., pp. 962-6), que sí basa una condena a varios empleados de una entidad financiera (miembros del llamado Comité de Dirección local de una sucursal) por no haber investigado suficientemente y por ello no comunicar la situación de funcionarios brasileños con abultadísimas cuentas que luego se demostraron procedentes de cohechos. El supuesto ilustra a la perfección las dificultades inherentes al hecho de que la condición de colaborador recaiga en personas jurídicas, lo que implica necesarios mecanismos de delegación, supervisiones en cadena, entrada en juego del programa de cumplimiento, etc. De todo ello se ocupa el último autor en op. cit., pp. 966 y ss.

106 Así, CANCIO MELIÁ, «Delitos de organización: criminalidad organizada común y delitos de terrorismo", en Díaz-Maroto y Villarejo (dir.), Estudios sobre las reformas del Código penal operadas por las LO 5/2010, de 22 de junio, y 3/2011, de 28 de enero, Civitas/ Thomson, Cizur Menor, 2011, pp. 643 y ss., p. 664, o GARCÍA ALBERO, «Comentario al art. 576», en Quintero Olivares (dir.)/Morales Prats (coord.), Comentarios al Código penal, $7^{\text {a }}$ ed., tomo II, Aranzadi, Cizur Menor, 2016, pp. 1913 y ss., p. 1918. Insisten 
tos. El origen del precepto se encuentra en la Directiva 2005/60/CE, de 26 de octubre, del Parlamento Europeo y del Consejo, sobre Prevención de Blanqueo de Capitales y de Financiación del Terrorismo, que obligaba a dar a la segunda fenomenología delictiva el mismo tratamiento que la primera recibiera en cada ordenamiento ${ }^{107}$; una equiparación que resulta compleja (especialmente, en lo que aquí interesa, respecto de las meras omisiones de comunicación) dada la poca claridad del supuesto modelo a seguir - como acaba de comentarse, no resulta nada claro si el art. 301.3 ha de interpretarse como una equiparación ex lege de la no comunicación a un blanqueo imprudente activo-. Da la impresión, con todo, de que la redacción típica del 576.4 sí se basa en esa idea: si no se informa de lo sospechoso (incumpliendo así una de las obligaciones del sujeto colaborador), y por tanto la operación no es detectada, se incurre en la pena del art. 576.4. Por otra parte, llama la atención la técnica de tipificación utilizada, completamente distinta a la del blanqueo: no se prevé una pena específica para esta "financiación del terrorismo imprudente» (activa u omisiva), sino que se hace depender (a través de una disminución en uno o dos grados) de la pena del delito doloso no evitado, que puede consistir también en una de las modalidades agravadas —una graduación no prevista en sede de blanqueo-. Se utiliza así una técnica de vinculación de la pena a la del delito no evitado que responde más a una estructura de participación (en lo que aquí interesa, en comisión por omisión) que a la de una mera omisión pura.

Con todo, si hubiera de entenderse (y ciertamente el 576.4 da pie para ello) que la no comunicación de una operación sospechosa que se produce sin ser detectada determina la responsabilidad penal del sujeto colaborador omitente, tal cosa supondría una desproporcionada dureza para con estos sujetos colaboradores que no dejan de ser profesionales privados. Ha de repararse en que en ninguno de los ámbitos que hemos examinado se incriminan de modo expreso ejecuciones descuidadas de deberes de vigilancia funcionariales que determinen que no sean impedidos delitos dolosos de terceros; de hecho, una previsión en esta dirección contenida en el anterior Código penal (una suerte de malversación imprudente omisiva: falta de vigilancia cuidadosa respecto de fondos públicos que son objeto de sustracción por parte de terceros) no se recoge en el texto de 1995, a pesar de que la posición de garantía del funcionario

ambos autores en la necesidad de reservar la calificación de terrorismo exclusivamente a conductas dolosas.

107 Lo recalca ZARAGOZA AGUADO, «Comentario al art. 576 Cp», en Gómez Tomillo (dir.), Comentarios prácticos al Código penal, tomo VI, Thomson/Aranzadi, Cizur Menor, 2015, pp. 645 y ss., p. 648. Muy crítico con la tipificación tanto del blanqueo como de la financiación del terrorismo imprudentes, que considera lesivas de los principios de proporcionalidad e intervención mínima, FERRÉ OLIVÉ, «Instrumentos internacionales en la lucha contra la financiación del terrorismo», en Ferré Olivé/Pérez Cepeda (dirs.), Financiación del terrorismo, Valencia, Tirant lo Blanch, 2018, pp. 57 y ss. 
responsable de los fondos resulta mucho más clara que la del sujeto colaborador, y de que el supuesto parece claramente más concebible en la práctica que las conductas omisivas imprudentes de blanqueo y financiación del terrorismo ${ }^{108}$. Y la misma conclusión arrojaría la comparación de responsabilidades respecto de conductas dolosas: si el 576.4 ha de interpretarse como una atribución ex lege de posición de garante y equivalencia normativa de la conducta de estos colaboradores con un blanqueo/ financiación imprudente activo, parece que esto hubiera de trasladarse a la no denuncia por parte de sujetos colaboradores en supuestos dolosos (así, empleado bancario que solicita o acepta una compensación a cambio de no denunciar operaciones que claramente tiene por delictivas), cuya sanción como autoría/participación en comisión por omisión con el delito no evitado resultaría desproporcionada en relación con la responsabilidad de determinados funcionarios (al menos, con la determinada por el art. 412.3) no considerados garantes, siendo así que estos últimos suelen contar con posibilidades de intervención que pueden permitir una paralización inmediata del delito en ejecución - detención en el caso de policías-que no forman parte de las atribuciones de los sujetos privados colaboradores, a los que solo cabe transmitir - a menudo a través de sus superiores- la información al SEPBLAC ${ }^{109}$.

108 «El funcionario que por abandono o negligencia inexcusables diere ocasión a que se efectúe por otra persona la sustracción de caudales o efectos públicos de que se trata en los números $2^{\circ}, 3^{\circ}$ y $4^{\circ}$ del artículo anterior, incurrirá en pela pena de multa de la mitad al tanto del valor de los caudales o efectos sustraídos, sin que pueda bajar de 100.000 pesetas». Un ejemplo de las críticas doctrinales formuladas en su día a dicho precepto por constituir un adelanto excesivo de las barreras de intervención, en DE LA MATA BARRANCO/ETXEBARRIA, Malversación y lesión del patrimonio público, Bosch, Barcelona, 1995, p. 26. Aun no existiendo tipo específico, la imputación por imprudencia al funcionario que por un ejercicio inadecuado de sus deberes de vigilancia no detiene el delito doloso de un tercero sería teóricamente posible en los delitos contra el medioambiente (ex art. $331 \mathrm{Cp}$ ) o contra la seguridad e higiene en el trabajo (ex art. 317 $\mathrm{Cp}$ ) - siempre, claro está, que dogmáticamente se admita esta estructura- pero no en el ámbito de la ordenación del territorio, que al igual que el ya citado de la malversación no cuenta con tipo imprudente.

109 Desproporción aun más clara si los tipos de los arts. 301.3 y 576.4 Cp se entendieran también aplicables a la mera no denuncia de operaciones ya realizadas - esta sería una intelección posible del hecho de que el segundo de ellos diferencie entre no haber sido posible «impedir» $\mathrm{y}$ "detectar» la financiación-, caso en el que las penas por blanqueo o financiación dolosos (incluso aunque fueran no de autoría sino con la rebaja de la complicidad) resultarían inadmisibles comparadas con las del art. 408 Cp (inhabilitación de no más de dos años para el policía o el juez que no persiguen un homicidio del que tienen noticia). Solo el entendimiento del blanqueo (o la financiación) como delitos de estructura materialmente próxima a los delitos permanentes (en la línea comentada supra respecto del delito fiscal) puede permitir dar un mínimo sentido a la sanción penal del sujeto colaborador que no comunica una operación sospechosa ya realizada. 


\section{ALGUNAS REFLEXIONES.}

De todo lo examinado hasta ahora pueden extraerse algunas conclusiones.

El conjunto de tipos omisivos específicos que hemos examinado constituye una regulación a mi juicio confusa y sistemáticamente poco coherente, que propicia disfunciones valorativas y no pocas vulneraciones del principio de proporcionalidad, fallas que su aplicación jurisprudencial tampoco ha contribuido a paliar. No se trata ahora de reiterar las dudas y problemas que hemos ido planteando en cada uno de los apartados anteriores: baste resaltar que, como ha podido comprobarse, cada uno de estos tipos plantea serias dificultades respecto de su relación con las cláusulas generales de la comisión por omisión, así como en cuanto a sus implicaciones de cara a la valoración de supuestos cercanos pero que no se encuentran (en función de un criterio de selección a menudo poco explicable) expresamente previstos. Lograr la coherencia sistemática por vía interpretativa se antoja en todos ellos tarea imposible, pues la solución de un problema suele propiciar una disfunción por un flanco distinto.

Así las cosas - y para no limitar estas páginas a una mera acumulación de críticas, siempre más sencillas de formular que las propuestas de mejora- cabe preguntarse por las posibilidades de acometer una reforma legislativa de estas conductas omisivas de funcionarios públicos que por una parte clarificara aspectos hoy sujetos a enormes divergencias interpretativas y por otra permitiera alcanzar una mayor armonía entre las penas asignadas a sus respectivos injustos, y entre todo ello y el régimen general de la comisión por omisión. En esta línea podrían formularse algunas sugerencias de principio (por supuesto necesitadas de mucha mayor afinación) que quizás podrían ayudar a solventar algunos de los problemas e incoherencias punitivas que hemos ido poniendo de manifiesto en estas páginas.

1. En el escalón más bajo debería siempre situarse la no intervención de particulares para impedir delitos, cuya pena parece lógico modular, como ya ocurre en el actual art. 450, en función de la gravedad del delito no impedido.

2. El tipo de no persecución de delitos por funcionario obligado a iniciarla (actual art. $408 \mathrm{Cp}$ ) debería describirse en términos excluyentes de la no intervención ante delitos todavía en ejecución (también la permanente o continuada). Al margen de los sujetos activos que suelen incluirse en el delito (policías, jueces, fiscales...), tendrían aquí cabida las conductas de inspectores que no denuncian conductas delictivas ya conclusas; en caso de considerarse necesaria una mayor dureza en ámbitos especialmente sensibles que han padecido una cierta dejadez en este sentido por 
parte de la Administración —como ocurre en la actualidad en delitos contra el medioambiente y ordenación del territorio- habría de tenerse muy presente la necesidad de guardar coherencia en las penas asignadas: carece de todo sentido prever una pena mayor para un inspector que no denuncia unos vertidos delictivos ya producidos y conclusos (por no hablar de la no denuncia de meras infracciones administrativas, supuesto este último que un sector doctrinal entiende subsumible en los arts. 320 y $329 \mathrm{Cp}$ ) que a un policía, un fiscal o un juez que no inician la persecución de (por poner un ejemplo obvio) un homicidio.

3. La no intervención de miembros de las FFCCSS para impedir delitos (de inminente o actual ejecución) contra bienes jurídicos personales podría contenerse en un tipo genérico como el actual art. 412.3 pero desprovisto del elemento típico del requerimiento (cuyo carácter disfuncional hemos podido comprobar) y con pena -modulada en función de la gravedad del delito no impedido y del hecho de encontrarse el agente o no de servicio- mayor que el tipo referido a particulares. Se trataría de un tipo residual, destinado a cubrir los casos (en realidad poco frecuentes) en que el funcionario policial «se encuentra» con el delito.

4. Para cubrir los supuestos de no intervención de funcionarios (especialmente miembros de las FFCCSS) en una posición que hemos denominado intermedia, próxima a la garantía (no evitación de delitos en Comisaría, prisiones o incluso en la vía pública - cometido normalmente por un compañero del Cuerpo- pero siendo dudosa la garantía por custodia, o tolerancia con delitos continuados de tráfico de drogas o contrabando por parte de miembros de unidades específicamente creadas para impedirlos) podría valorarse la introducción de un tipo omisivo que aproximara la pena a la de una complicidad omisiva, asignando al agente la pena inferior en uno o dos grados a la del delito no evitado (personalmente, no considero que el hecho de que se trate de torturas del art. 174 o maltrato del art. 175 debiera introducir especificidades respecto de la pasividad ante otros delitos -lesiones, agresión sexual, homicidio o asesinato-). Para permitir una solución coherente con las reglas generales de la comisión por omisión en casos en que sí concurra una clara posición de garantía (como los deberes de custodia en comisaría o prisiones, o los derivados de custodia/ control de menores en centros educativos), tendría sentido incluir una cláusula expresa de subsidiariedad respecto del art. 11, que aclarase que el precepto no será de aplicación en supuestos que de acuerdo con las reglas generales debieran merecer una sanción mayor (lo cual requeriría valorar asimismo la relación de equivalencia). 
5. En lo que se refiere a la no intervención ante el delito por parte de funcionarios con competencias de inspección, hemos podido comprobar que las actuales regulaciones específicas de las prevaricaciones omisivas en materia medioambiental o urbanística no han aportado seguridad jurídica ni racionalidad punitiva alguna a la materia, sino todo lo contrario; su singularización a través de dicha tipificación expresa, por otra parte, no parece tampoco imprescindible desde una óptica político-criminal, como pone de manifiesto su muy infrecuente aplicación práctica. A mi entender, en línea de principio el funcionario que asume (y de hecho inicia) la inspección de una actividad determinada —en cualquiera de los ámbitos en los que el Estado dispone de un cuerpo específico a tal efecto- sí se encuentra en posición de garantía respecto de la neutralización de los delitos que en ella puedan estar cometiéndose (permanentes o continuados), y probablemente resulte bastante el recurso a las reglas generales de la participación por omisión - por existir además una identidad normativa con la facilitación activa-; en este último sentido, la conducta de inspectores legitimados para clausurar o suspender por sí mismos la actividad (que a pesar de constarles la existencia de delito renuncien a ello y a realizar cualquier otra intervención) equivaldría a una cooperación necesaria omisiva en el delito no evitado, mientras que la de quienes solo cuenten con atribuciones de informar para que otros pongan en marcha el mecanismo destinado a intervenir correspondería al desvalor de una complicidad omisiva. En cualquier caso, de no aceptarse que la condición de inspector suponga una posición de garante o que exista una verdadera relación de equivalencia, parecería lógico otorgarles el mismo tratamiento que a las situaciones intermedias descritas en el número anterior, con una pena que pudiera llegar a ser rebajada en dos grados respecto del delito no evitado - pero sin renunciar a que la pena se hiciera depender de la de este último-.

6. Carece de sentido que - como ocurre en la actualidad-conductas omisivas de sujetos privados (a los que por necesidades político-criminales se asignan deberes de colaboración jurídicopúblicos) reciban mayor pena que las de funcionarios públicos en situaciones asimilables. Al margen de que ya de entrada resulte muy cuestionable la necesidad de un refuerzo penal de tales deberes, en caso de optarse por disponerlos nunca deberían dar lugar a mayor responsabilidad que la del funcionario, y parece difícil que dicha coordinación pueda lograrse si — como acontece al menos en el art. 576.4 Cp- se opta por tipificar como delito imprudente el defecto de vigilancia del que trae causa la no neutralización de un delito doloso de un tercero (una vía que en cambio no se arbitra para funcionarios, y que solo sería residualmente posible en función de la existencia de modalidades imprudentes 
del delito en cuestión). Si un defecto de vigilancia o una ejecución descuidada de su cometido por parte de un funcionario encargado de fondos públicos, un agente de aduanas o un inspector de Hacienda (que respectivamente no detectan una apropiación de fondos por un tercero, un tráfico de drogas o un delito fiscal) no puede comportar responsabilidad alguna por imprudencia, resulta claramente lesivo del principio de proporcionalidad que tal cosa sí suceda respecto de sujetos privados; la manera más correcta de solventar esta asimetría no parece transitar por una igualación al alza, sino, por el contrario, por la derogación de los tipos indicados y la remisión de las responsabilidades, en su caso, a vías extrapenales.

\section{BIBLIOGRAFÍA CITADA}

ACALE SÁNCHEZ, «Tutela penal del medio ambiente y funcionarios públicos», en Quintero Olivares/Morales Prats (coords.), Estudios de Derecho ambiental. Libro homenaje al prof. Miquel Prats Canut, Tirant lo Blanch/Universitat Rovira i Virgili, Valencia, 2008, pp. 819 y ss.

Alastuey Dobón, «El ámbito de aplicación del art. 329 Cp. Examen de sus conductas típicas», $R D P C, 2^{\mathrm{a}}$ época, núm. 9 (2002), pp. 11 y ss.

Bacigalupo Zapater, Delitos impropios de omisión, Dykinson, Madrid, 2005.

BARQUín SÁNCHEZ, Los delitos de tortura y tratos inhumanos o degradantes, Edersa, Madrid, 1992.

- Delitos contra la integridad moral, Bosch, Barcelona, 2001.

Bermejo, Prevención y castigo del blanqueo de capitales. Un análisis jurídico-económico, Marcial Pons, Madrid/Barcelona/Buenos Aires/ Sao Paulo, 2015.

Beulke, Werner/Sowoda, Sabine, «Beschützergarant Jugendamt. Zur Strafbarkeit von Mitarbeitern des Jugendamtes bei Kindestod, Kindesmisshandlung oder -missbrauch innerhalb der betreuten Familie», en Dölling (hrsg.), Festschrift für Karl Gössel zum 70. Geburstag», Müller Verlag, Heidelberg, 2002, pp. 73 y ss.

Blanco Cordero, El delito de blanqueo de capitales, $4^{\mathrm{a}}$ ed (2 $2^{\mathrm{a}}$ en Grandes Tratados), Thomson Reuters/Aranzadi , Cizur Menor, 2015.

BOLEA BARDON, «Posiciones de garante frente al acoso escolar: ¿Responden penalmente los padres y docentes que no impiden el acoso?», InDret 4/2017.

BRAMmSEn, Die Entsetehungsvoraussetzungen desr Garatenpflichten, Duncker und Humboldt, Berlin, 1986. 
BRINGEWAT, «Kommunale Jugendhilfe und strafrechtliche Garantenhaftung», NJW 1998, 944 y ss.

CANCIO Meliá, «La responsabilidad del funcionario por delitos contra el medio ambiente en el Código penal español», ADPCP vol. LII, 1999, pp. 137-76.

— «Delitos de organización: criminalidad organizada común y delitos de terrorismo», en Díaz-Maroto y Villarejo (dir.), Estudios sobre las reformas del Código penal operadas por las LO 5/2010, de 22 de junio, y 3/2011, de 28 de enero, Civitas/Thomson, Cizur Menor, 2011, pp. 643 y ss.

Coca VILA, «Tirar a matar en cumplimiento de un deber. Una aproximación al fundamento y límites de los deberes positivos de protección policial», RECPC 19-24 (2017).

CRAMER, «Tod eines von Sozialarbeiterin betreuten Kindes. Anmerkung», NStZ 1997, pp. 238-9.

CuERDA ARNAU, «Lección X. Torturas y otros delitos contra la integridad moral», en González Cussac (coord.), Derecho penal Parte Especial, $5^{\mathrm{a}}$ ed., Tirant lo Blanch, Valencia, 2016, p. 177 y ss.

DIAS, LEANDRO, «División de tareas y responsabilidad por omisión del funcionario policial», Lecciones y Ensayos, núm.95, 2015, pp. 387 y ss.

Díez Ripollés, «La Responsabilidad Penal De Las Personas Jurídicas. Regulación española», InDret 1/2012.

Dopico Gómez-ALLER, «Posición de garante del compliance officer por omisión del 'deber de control': una aproximación tópica», en Arroyo Zapatero/Nieto Martín (dirs.), El Derecho penal económico en la era compliance, Tirant lo Blanch, Valencia, 2013, pp. 165 y ss.

FeIJoo Sánchez, Homicidio y lesiones imprudentes. Requisitos y límites materiales, Madrid, Edijus, 1999.

— «Delitos contra la Administración pública: consideraciones generales, nuevas figuras delictivas y modificación de otras conocidas», Diario La Ley, 22430/2001.

FERRÉ OlIVÉ, «Instrumentos internacionales en la lucha contra la financiación del terrorismo», en Ferré Olivé/Pérez Cepeda (dirs.), Financiación del terrorismo, Valencia, Tirant lo Blanch, 2018, pp. 57 y ss.

García Albero, «Comentario al art. 576», en Quintero Olivares (dir.)/ Morales Prats (coord.), Comentarios al Código penal, $7^{\mathrm{a}}$ ed., tomo II, Aranzadi, Cizur Menor, 2016, pp. 1913 y ss.

García Del Blanco, Victoria, «Tortura», en Memento Penal 2019, Francis Lefebvre, Madrid, 2019, ns.ms. 8880 y ss. 
García Moreno, «Whistleblowing como forma de prevención de la corrupción en la administración pública», en Nieto Martín/Maroto Calatayud (dirs.), Public Compliance, prevención de la corrupción en administraciones públicas y partidos políticos, Eds. Universidad Castilla-La Mancha, Cuenca, 2014, pp. 43 y ss.

García Valverde, Francisco, «Responsabilidad penal derivada del acoso escolar», en Rivas Vallejo, Pilar/García Valverde, Maria Dolores (dras.), Tratamiento integral del acoso, Thomson/Aranzadi, Cizur Menor, 2015, pp. 390 y ss.

GIMBERNAT ORDEIG, «La omisión impropia en la dogmática penal alemana: una exposición», $A D P C P$, vol. L, 1997, pp. 1 y ss.

Gómez Tomillo, Urbanismo, función pública y Derecho penal, Comares, Granada, 2000

— «ART. 320», y «Artículo 329», en Gómez Tomillo (dir.), Comentarios prácticos al Código penal, Tomo IV, Thomson Reuters-Aranzadi, Cizur Menor, 2015, pp. 53 y ss., pp.129 y ss., respectivamente.

- Compliance penal y política legislativa. El deber personal y empresarial de evitar la comisión de ilícitos en el seno de las personas jurídicas, Tirant lo Blanch, Valencia, 2016.

GonZÁLEz ALONSO, «Sobre la responsabilidad patrimonial del Estado-Juez por delitos cometidos por condenados en libertad condicional, en tercer grado penitenciario o en disfrute de un permiso penitenciario", Diario La Ley n ${ }^{\circ}$ 6896, 4 marzo 2008.

GoNZÁLEZ CuSSAC, «Sobre la prevaricación específica en los delitos contra el medio ambiente», en Quintero Olivares/Morales Prats (coords.). Estudios de Derecho ambiental. Libro homenaje al prof. Miquel Prats Canut, Tirant lo Blanch/Universitat Rovira i Virgili, Valencia, 2008, pp. 995 y ss.

GÓRRIZ Royo, Los delitos de prevaricación urbanística, Tirant lo Blanch, Valencia, 2004.

— «Omisión y tolerancia administrativa en Derecho penal del medioambiente, a propósito del art. $329.1 .2^{\circ} \mathrm{Cp}$ ", Revista de derecho y proceso penal, núm. 14, 2005, pp. 25 y ss.

— «Delitos contra los recursos naturales y el medio ambiente (arts. 325, 326 bis, 327 y 328 CP), en González Cussac (dir.), Comentarios a la reforma del Código penal de 2015, $2^{\mathrm{a}}$ ed., Tirant lo Blanch, Valencia, 2015, pp. 1007 y ss.

— «Prevaricaciones urbanísticas del art. 320: problemas legislativos no resueltos y dificultades aplicativas en la práctica reciente», EPC XXXVIII extr.2018, pp. 101 y ss. 
GRIMA LIZANDRA, «Los delitos de tortura y de otros tratos inhumanos o degradantes cometidos por funcionarios públicos», CDJ 1996 (30), pp. 137 y ss.

Hassemer, R. «Garantenpflicht, Fachlichkeit und Technologiedefizit», en Herzog/Neumann (Hrsg.), Festschrift für Winfried Hassemer, Müller Verlag, Heidelberg, 2010, pp. 729 y ss.

Huerta Tocildo, Principales novedades de los delitos de omisión en el Código penal de 1995, Valencia, Tirant lo Blanch, 1997.

— «La regulación de la comisión por omisión en el art. 11 Cp. Balance y problemas no resueltos», en Maqueda Abreu et.al (coords.), Derecho Penal para un estado social y democrático de derecho, Estudios penales en homenaje al profesor Emilio Octavio de Toledo, Universidad Complutense de Madrid, 2016, pp. 137 y ss.

Lafont Nicuesa, El delito de acoso moral en el trabajo, Tirant lo Blanch, Valencia, 2008.

LASCURÁIN SÁnCHEZ, «De las torturas y otros delitos contra la integridad moral», en Bajo Fernández (dir.), Compendio de Derecho penal PE, vol II, Centro de Estudios Ramón Areces, Madrid, 1998, pp. 84 y ss.

- Los delitos de omisión: fundamento de los deberes de garantía, Civitas, Madrid, 2002.

- Lección 3, "La responsabilidad individual en los delitos de empresa», en De la Mata/Dopico/Lascuráin/Nieto, Derecho penal económico y de la empresa, Dykinson, Madrid, 2018, pp. 87 y ss.

LAUBENTHAL, «Privates Wissen und strafrechtliche Verantwortlichkeit von Polizaibeamten», en Heinrich et.al (Hrsg), Festschrift für Ulrich Weber zum 70. Geburtstag, Gieseking Verlag, Bielefeld, 2004, pp. 109 y ss.

LuZón Peña, Lecciones de Derecho penal Parte General, $3^{\text {a }}$ ed., Tirant lo Blanch, Valencia, 2016.

Martínez Garay, «¿Seguridad jurídica o seguridad de los bienes jurídicos? Sobre el nuevo papel de los derechos fundamentales en el discurso jurídico-penal», en Vives Antón et.al, Acción significativa, comisión por omisión y Derecho penal, Tirant lo Blanch, Valencia, 2017, pp. 267 y ss.

De La Mata Barranco, «La obligación de control de la Administración en relación a delitos cometidos por particulares. El ejemplo de los delitos contra el ambiente», en Asúa Batarrita (ed.), Delitos contra a Administración Pública, IVAP, Bilbao, 1997, pp. 391 y ss.

De La Mata BarRanco/EtXebarria, Malversación y lesión del patrimonio público, Bosch, Barcelona, 1995.

Mir Puig, S., Derecho penal Parte General, 10ª ed., Reppertor, Barcelona, 2015. 
MiR PUIG, C., «La malversación y el nuevo delito de administración desleal en la reforma de 2015 del Código Penal español», ADPCP, vol. LXVIII, 2015, pp. 185 y ss.

Molina FernánDEZ, «¿Qué se protege en el delito de blanqueo de capitales?: reflexiones sobre un bien jurídico problemático, y a la vez aproximación a "participación» en el delito», en Bajo Fernández/ Bacigalupo (eds.), Política criminal y blanqueo de capitales, Marcial Pons, Madrid, 2009, pp. 91 y ss.

Morales Garcia, Los delitos de malversación, Aranzadi, Cizur Menor, 1999.

Morales Prats/Rodríguez Puerta, «Art. 408», en Quintero Olivares (dir.)/Morales Prats (coord..), Comentarios al Código penal español, $7^{\text {a }}$ ed., Tomo II, Thomson Reuters/Aranzadi, Cizur Menor, 2017.

Muñoz Conde, Derecho penal Parte Especial, 22 a ed., Tirant lo Blanch, Valencia, 2019.

MuÑOZ Cuesta, «Omisión del deber de perseguir delitos: consentir actividad delictiva a confidente de la policía», Repertorio de jurisprudencia Aranzadi, $\mathrm{N}^{\mathrm{o}} 7,2006$, pp. 21151 y ss.

MuÑz SÁnchez, Los delitos contra la integridad moral, Tirant lo Blanch, Valencia, 1999.

Nieto Martín, La responsabilidad penal de las personas jurídicas: un modelo legislativo, Iustel, Madrid, 2008.

- «La privatización de la lucha contra la corrupción», en Arroyo Zapatero/Nieto Martín, El Derecho penal económico en la era compliance, Tirant lo Blanch, Valencia, 2013, pp. 191 y ss.

PASTRANA I ICART, LlUIS-IgNASI, La responsabilitat penal del funcionari de presons: aspectes omissius : (un estudi sobre la infracció dels deures d'intervenció en l'àmbit penitenciari), Bosch, Barcelona, 1998.

PAWLIK, «El funcionario policial como garante de impedir delitos», InDret $1 / 2008$.

PEÑARANDA RAMOS, «Sobre responsabilidad en comisión por omisión respecto de hechos delictivos cometidos en la empresa (y en otras organizaciones)», Derecho y Justicia penal en el s. XXI, Liber amicorum en Homenaje al profesor Antonio González Cuéllar, Colex, Madrid, 2006, pp. 411 y ss.

- Capítulo 6, «Tipicidad en los delitos omisivos», Memento Penal 2019, Francis Lefebvre, Madrid, 2019.

PuPPE, «Verantwortlichkeit von Klinikärtzen für von Untergebrachtem bei Ausgand begangene Straftaten«, NStZ 2004, 554-6. 
Quintero Olivares, «ART. 450», en Quintero Olivares (dir.)/Morales Prats (coord..), Comentarios al Código penal español, $7^{\mathrm{a}}$ ed., Tomo II, Thomson Reuters/Aranzadi, Cizur Menor, 2017.

RaguÉs I Vallès, Whistleblowing, Una aproximación desde el Derecho penal, Marcial Pons, 2013.

REBOLlo VARGAS, «La omisión de promover la persecución de delitos. El artículo 408 del código penal», Revista de Derecho y proceso penal, núm. 2, 1999, pp. 13 y ss.

- «De las torturas y otros delitos contra la integridad moral», en Córdoba Roda/García Arán (dirs.), Comentarios al Código penal. Parte Especial, Tomo I, Marcial Pons, Barcelona, 2004, pp. 229 y ss.

RIVERo ORTEGA, El Estado vigilante: consideraciones jurídicas sobre sobre la función inspectora de la Administración, Tecnos, Madrid, 1999.

Robles Planas, «Los dos niveles del sistema de intervención en el delito (El ejemplo de la intervención por omisión)» InDret 2/2012.

— «Deberes negativos y positivos en Derecho penal», InDret 4/2013.

Roca Agapito; El delito de malversación de caudales públicos, Bosch, Barcelona, 1999.

RODRíguez Mesa, Torturas y otros delitos contra la integridad moral cometidos por funcionarios públicos, Comares, Granada, 2000.

RODRÍGUEZ-VILLASANTE Y PRIETO, «De las torturas y otros delitos contra la integridad moral», EDJ 1996 (2), PP. 87 y ss.

RoXIN, «Anmerkung», StV 9/2004, p. 484.

- Strafrecht Allgemeiner Tat, tomo II, Beck, München, 2003.

Rubio LaRa, Denegación de auxilio por funcionario público, CESEJ Ediciones, Madrid, 2006.

RUEDA MARTín, M ${ }^{\mathrm{a}}$ ÁNGELES, ¿Participación por omisión? Un estudio sobre la cooperación por omisión en un delito de acción doloso cometido por un acción principal, Atelier, Barcelona, 2013.

SALIGER, "Strafrechtliche Verantwortung eines Arztes für Taten eines Straftäters während des Ausganges» JZ 2004, pp. 975 y ss.

SÁNCHEZ OSTIZ GuTIÉRREZ, «Funcionario que no promueve la persecución de delitos: un caso entre el encubrimiento y la omisión del deber de impedir delitos», ADPCP 1996, pp. 1047 y ss.

SÁNCHEZ Ostiz GuTIÉRREZ, La exención de responsabilidad penal por regularización tributaria, Aranzadi, Cizur Menor, 2002.

SCHAFFSTEIN, «Die strafrechtliche Verantwortlichkeit Vollzugsbediensteter für den Missbrauch von Vollzugslockerungen», en Festschrift für Karl Lackner zum 70. Geburstag, de Gruyter, Berlin/New York, 1987, pp. 795 y ss. 
Schultz, Amtswalterunterlassen, Duncker \& Humblot, Berln, 1984.

SchÜNEMANN, «Die Unterlassungsdelikte und die strafrechtliche Verantwortlichkeit für Unterlassungen», ZStW 97 (1984), pp. 287 y ss.

SERrano González De Murillo, «La responsabilidad penal de los miembros de las fuerzas policiales por no impedir delitos», $R D P C 3^{\text {a }}$ Época núm. 2 (2009), pp. 127 y ss.

SILVA SÁNCHEZ, «Muerte violenta del recluso en un centro penitenciario: ¿solo responsabilidad patrimonial de la Administración o también responsabilidad penal de los funcionarios?», ADPCP 44 (1991), pp.561 y ss.

- Delitos contra el medio ambiente, Tirant lo Blanch, Valencia, 1999.

— «Hacia el Derecho penal del «Estado de la prevención». La protección penal de las agencias administrativas de control en la evolución de la Política Criminal», en Silva Sánchez (dir.), ¿Libertad económica o fraudes punibles?, Marcial Pons, Madrid-Barcelona 2003, pp. 307 y ss.

— «La intervención de notarios en la comisión de delitos patrimoniales y económicos», en Judicatura y notariado ante los delitos económicos, EDJ núm. 73, CGPJ, Madrid, 2006, pp. 167 y ss.

— «Los delitos patrimoniales y económico-financieros», Diario La ley núm. 7534 (23-12-2010).

TAmarit Sumalla, «Comentario al art. 176», en Quintero Olivares (dir.)/ Morales Prats (coord..), Comentarios al Código penal Español. Tomo I (arts.1-233), $7^{\mathrm{a}}$ ed., Thomson Reuters/Aranzadi, Cizur Menor, 2016, pp. 1224 y ss.

Tomás-Valiente LanuZa, El efecto oclusivo entre causas de justificación, Comares, Granada, 2009.

— « ¿Y si el Sheriff Calder hubiera permitido el linchamiento de Bubber Reeves? La Jauría Humana y el funcionario policial como garante de la evitación de delitos» en Vives Antón et.al. (dirs.), Crímenes y castigos, Miradas al Derecho penal a través del arte y la cultura, Tirant lo Blanch, Valencia, 2014, pp. 859 y ss.

— "Comentario a los arts. 413-418 (infidelidad en la custodia de documentos y de la violación de secretos)» en Gómez Tomillo (dir.), Comentarios prácticos al Código Penal, tomo V, Thomson-ReutersAranzadi, Cizur Menor, 2015, pp. 249 y ss.

— «Deberes positivos del Estado y Derecho penal en la jurisprudencia del Tribunal Europeo de Derechos Humanos,» InDret Penal 3/2016.

VACCHELLI, «En los límites del rol. Los conocimientos especiales del funcionario público», InDret 4/2017.

WeIGEND, Leipziger Kommentar, de Gruyter, Berlin, 2019, com. §13. 
VIADA BARDAJí, «Necesarias medidas de compliance en el sector público», en Frago Amada (coord..), Actualidad Compliance 2018, Thomson/ Aranzdi, Cizur Menor, 2018, pp. 187 y ss.

ZACZYK, «Sobre la posición de garante de los funcionarios», en Libertad, derecho y fundamentación de la pena, Universidad Externado de Colombia, 2010, pp. 321 y ss.

Zaragoza Aguado, «Comentario al art. 576 Cp», en Gómez Tomillo (dir.), Comentarios prácticos al Código penal, tomo VI, Thomson/Aranzadi, Cizur Menor, 2015, pp. 645 y ss. 